\title{
Trends in recombinant protein use in animal production
}

\author{
Laia Gifre ${ }^{1}$, Anna Arís ${ }^{1}$ Àlex Bach ${ }^{1,2}$ and Elena Garcia-Fruitós ${ }^{1 *}$ (1)
}

\begin{abstract}
Recombinant technologies have made possible the production of a broad catalogue of proteins of interest, including those used for animal production. The most widely studied proteins for the animal sector are those with an important role in reproduction, feed efficiency, and health. Nowadays, mammalian cells and fungi are the preferred choice for recombinant production of hormones for reproductive purposes and fibrolytic enzymes to enhance animal performance, respectively. However, the development of low-cost products is a priority, particularly in livestock. The study of cell factories such as yeast and bacteria has notably increased in the last decades to make the new developed reproductive hormones and fibrolytic enzymes a real alternative to the marketed ones. Important efforts have also been invested to developing new recombinant strategies for prevention and therapy, including passive immunization and modulation of the immune system. This offers the possibility to reduce the use of antibiotics by controlling physiological processes and improve the efficacy of preventing infections. Thus, nowadays different recombinant fibrolytic enzymes, hormones, and therapeutic molecules with optimized properties have been successfully produced through cost-effective processes using microbial cell factories. However, despite the important achievements for reducing protein production expenses, alternative strategies to further reduce these costs are still required. In this context, it is necessary to make a giant leap towards the use of novel strategies, such as nanotechnology, that combined with recombinant technology would make recombinant molecules affordable for animal industry.
\end{abstract}

Keywords: Recombinant proteins, Animal production, Recombinant expression systems, Reproductive hormones, Fibrolytic enzymes, Therapeutic molecules

\section{Background}

Unquestionably, the production of recombinant proteins has become a reality thanks to the discovery of the recombinant DNA technology in the seventies. The implementation of this technology has made the production of most protein of interest recombinantly possible. Before this, proteins of interest were extracted from their natural sources through expensive processes and poor yields [1]. However, nowadays, scientists can routinely isolate or synthesize genes and clone them in a suitable expression system for production purposes at industrial scale. Although there is a wide range of cell factories that are currently used for recombinant protein production

\footnotetext{
${ }^{*}$ Correspondence: elena.garcia@irta.cat

${ }^{1}$ Department of Ruminant Production, Institut de Recerca i Tecnologia

Agroalimentàries (IRTA), 08140 Caldes de Montbui, Spain

Full list of author information is available at the end of the article
}

purposes, including bacteria, yeast, fungi, algae, insect cells, and mammalian cells [2], the bacterium Escherichia coli has become the workhorse in this field. This is not only due to the low production costs associated to this prokaryotic expression system, but also to the number of available tools that makes this process easy to implement. The first functional recombinant protein (somatostatin) was produced in 1977 using E. coli as cell host [3] and, just some years later, Genentech Inc. launched a recombinant human insulin also produced in $E$. coli.

However, despite the undeniable advances made in the recombinant protein production field, production processes, and more importantly downstream product processing, have important associated costs. This is particularly limiting for the production of recombinant proteins for animal science, where the development of low-cost products and strategies are a priority. 
Despite the existence of some limitations, the use of recombinant proteins in animal science has clearly increased in the last decades. Looking at the overall bibliography where recombinant proteins are being used, it comes out that one of the most studied field is the endocrine system [4-8]. Indeed, there are already some commercial recombinant hormones available and many groups are working on their implementation to improve reproduction of livestock. Many research studies also focus on less-demanded proteins that need specific customization of production procedures according to particular features. Recombinant engineered proteins are being widely explored for the design of both prophylactic treatments and therapeutic strategies. Also, several enzymes are being recombinantly produced with the aim of improving efficiency of feed conversion into edible products.

This article offers an overview of recombinant proteins produced in microbial cell factories, focusing in three fundamental pillars for animal production: (1) reproduction, (2) feed efficiency, and (3) health. This review seeks not only to draw a map of the current situation, but also to highlight the relevance that recombinant technologies could have in a near future for the animal sector. However, all the recombinant products involved in vaccination procedures have been excluded from this revision because they have been thoroughly covered in other articles and reviews [9-11].

\section{Recombinant hormones in reproduction}

Animal reproduction is one of the areas where production of recombinant protein is broadly used [4, 12, 13]. Reproductive hormones have a critical role in the regulation of the male reproductive function, female reproductive cycle, and the maintenance of pregnancy in the dams. In animal production, these hormones are used for two opposite purposes: enhancing female fertility by regulating ovulation and/or facilitating embryo implantation, and on the other hand improving meat quality by sterilized males.

Follicle stimulating hormone (FSH) and luteinizing hormone (LH) are gonadotropins secreted by the anterior pituitary gland when induced by the gonadotropin releasing hormone $(\mathrm{GnRH})$, secreted by the hypothalamus [14-16]. These glycoproteins, together with the chorionic gonadotropin (CG) secreted by the placenta of primates and equids, are used in animal breeding management for superovulation purposes in females, and to stimulate testosterone production and spermatogenesis in males. On the other hand, inhibin, which is secreted by both male and female gonads, has a great importance because it exerts a negative feedback to the anterior pituitary lowering the secretion of gonadotropin and thus their effects.

At present, the most commonly used hormones for reproductive purposes are purified from animal-derived material such as pituitaries. Despite being a widespread practice, it has significant associated problems such as: (i) batch-to-batch inconsistencies leading to variations in the superovulatory responses between animals [17, 18], (ii) purity problems because of the presence of other hormones contaminating the sample [16], and (iii) the possible contamination with disease-transmitting agents (for a more detailed review see [13]). All these require the development and application of cumbersome purification protocols to concentrate and purify the protein to guarantee the quality of the final product. In this context, production of recombinant hormones appears as an attractive solution to overcome these drawbacks, having reproducible superovulation effects [12] by using considerably smaller doses than those utilized with animalderived hormones [19].

Gonadotropins are structured in non-covalent heterodimers, composed of a common $\alpha$ subunit and a hormone-specific $\beta$ subunit. To obtain a functional hormone, both subunits must be assembled together $[14,20]$ posing an important bottleneck for its recombinant production. However, and because the interaction between subunits is not an absolute requirement for receptor activation ([21] and references therein), functional single-chain gonadotropin analogs have been successfully developed recombinantly by merging their $\alpha$ and $\beta$ subunit genes in a single sequence [21-24]. Nevertheless, and even if the steroidogenic response is achieved, the structural differences in the hormone analogs commonly imply differences in steroid secreted levels [21]. Furthermore, the 2 subunits of gonadotropins are glycosylated after translation generating pools of different glycoforms (gonadotropin varieties) with different half-lives and activity efficiencies [25, 26]. Thus, since reproductive hormones require a $\mathrm{N}$-glycosylation [20], recombinant production has been carried out mainly in mammalian or insect cells $[13,27]$. However, the production of proteins in large amounts in these eukaryotic systems is expensive, difficult, and time-consuming. Furthermore, protein hormones are usually produced at low yields. Alternatively, yeast (eukaryotic microorganisms), and in some cases $E$. coli, are being explored as a cost-effective and easy-to-work systems. Pichia pastoris (reclassified as Komagataella pastoris) is the most commonly used yeast in this context, because it efficiently secretes the protein produced and adds N-glycosylations. Even though P. pastoris can glycosylate proteins, it should be stressed that only one specific strain described 
by Jacobs et al. is able to introduce a mammalian-type N-glycosylation [28].

\section{Follicle stimulating hormone (FSH)}

FSH acts in ovaries in conjugation with LH. They are responsible of stimulating the granulose cells and promoting follicle growth preceding the ovulation stage. Also, both gonadotropins stimulate the dominant follicle to ovulate. In males, FSH is responsible for stimulating the Sertoli cells in testes for spermatogenesis, together with testosterone secreted by the action of LH in Leydig cells.

Administering exogenous FSH has been a typical practice for promoting superovulation and spermatogenesis in different animal species, and due to the disadvantages associated with pituitary-extracted hormones, recombinant hormone formulations started to rise. There are commercial forms of FSH derived from pituitary glands such as Folltropin-V (Bioniche Animal Health-now Vetoquinol-) and Pluset (Calier), which also contain LH (Table 1). The commercially-available recombinant FSH used for animal follicular development and superovulation has been mostly produced by Chinese hamster ovary $(\mathrm{CHO})$ cells. Some examples are Follistim (follitropin beta; Merck Serono (USA) -now Merck-), Puregon (follitropin beta; Organon B.V. (Europe) -now merged with MSD-) and Gonal-F (follitropin alpha; Merck). Also, AspenBio Pharma (named Venaxis, Inc. since 2012) tooks a relevant role as a supplier of bovine and equine singlechain and long-acting FSH analogs (BoviPureFSH ${ }^{\mathrm{TM}}$ and EquiPureFSH ${ }^{\mathrm{TM}}$ ) (Table 1). In some cases, human embryonic kidney (HEK) cells have been chosen as a cell factory to produce bovine FSH (Nanocore Biotecnologia SA) used to supplement culture medium for in vitro follicle development in mares [29], dogs [30], goats, and sheep [31] (Table 1). The equine reproduction research industry has clearly been a user and promoter of this drug to stimulate follicular growth $[6,19,32,33]$ and ovulation [34] in mares. Even so, although the human version of this long-acting and single-chain FSH, Elonva (Corifollitropin $\alpha$; MSD) was already available in 1992 [35-38], the bovine and equine analogs did not reach the market until 2008 [6].

Although all commercial recombinant FSH are produced in mammalian cell lines and research is still being conducted in this area $[39,40]$, yeasts, which are relatively inexpensive and effective expression systems, are gaining importance in this field of study. The most used yeast to produce $\mathrm{FSH}$ is $K$. pastoris. Bovine, porcine, ovine, and primate recombinant FSH have been produced with $K$. pastoris in studies carried out to improve the yields with this affordable cell factory [41-44]. Although in these studies the activity was only tested in vitro, results indicated that proteins produced were functional and with a great potential to be applied in vivo. K. pastoris was also explored for the production of in vitro tested single-chain

Table 1 Marketed follicle stimulating hormone (FSH), Luteinizing hormone (LH) and chorionic gonadotropin (CG) for animal reproduction

\begin{tabular}{|c|c|c|}
\hline Name & Cell factory/origin & Company \\
\hline \multicolumn{3}{|l|}{ FSH } \\
\hline Follistim ${ }^{\circledR}$ & $\mathrm{CHO}$ cells & Merck Serono (USA)-now Merck- \\
\hline Puregon ${ }^{\circledR}$ & $\mathrm{CHO}$ cells & Organon B.V. (Europe) -now merged with MSD- \\
\hline Gonal- $F^{\circledR}$ & $\mathrm{CHO}$ cells & Merck \\
\hline BoviPureFSH ${ }^{\mathrm{TM}}$ & $\mathrm{CHO}$ cells & AspenBio Pharma (Venaxis, Inc. since 2012) \\
\hline EquiPureFSH ${ }^{\mathrm{TM}}$ & $\mathrm{CHO}$ cells & AspenBio Pharma (Venaxis, Inc. since 2012) \\
\hline $\mathrm{FSH}$ & HEK cells & Nanocore Biotecnologia SA \\
\hline Folltropin- $V^{\circledR}$ & Pituitary gland & Bioniche Animal Health-now Vetoquinol- \\
\hline Pluset $^{\circledR}$ & Pituitary gland & Calier \\
\hline \multicolumn{3}{|l|}{ LH } \\
\hline BoviPureLH $\mathrm{H}^{\mathrm{TM}}$ & $\mathrm{CHO}$ cells & AspenBio Pharma (Venaxis, Inc. since 2012) \\
\hline EquiPureLH ${ }^{\mathrm{TM}}$ & $\mathrm{CHO}$ cells & AspenBio Pharma (Venaxis, Inc. since 2012) \\
\hline Luveris $^{\circledR}$ & $\mathrm{CHO}$ cells & Merck Serono (USA) -now Merck- \\
\hline Pluset $^{\circledR}$ & Pituitary gland & Calier \\
\hline \multicolumn{3}{|l|}{ CG } \\
\hline Pregnyl & Urine & Organon B.V. (Europe) -now merged with MSD- \\
\hline Folligon ${ }^{\circledR}$ & Serum & MSD \\
\hline Novormon ${ }^{\circledR} 5000$ & Chorion & Syntex \\
\hline PG600 ${ }^{\circledR}$ & Chorion and serum & MSD \\
\hline
\end{tabular}


ovine FSH analogs [45], as well as for the production of fish FSH that showed the capacity to stimulate steroidogenesis and ovarian development in vivo [46-48]. Moreover, eel FSH produced in K. pastoris has been proven in vitro, fostering steroidogenesis in immature eel testis tissue [49] and spermatogenesis [50] (for more information about recombinant fish gonadotropin development, see [27]). Also, the yeast Hansenula polymorpha (Pichia angusta) has been used to express bovine FSH, which has been successfully tested in vivo in mice for follicular growth purposes [51].

During the last decades, different strategies to increase FSH production in recombinant yeast have been evaluated including the co-expression of a disulfide isomerase [52], the co-expression of Saccharomyces cerevisiae-derived calnexin [51] or codon usage optimization $[51,52]$. Medium optimization has also been deeply studied to optimize cell densities and production yields [53]. Thus far, although the yields achieved using both $K$. pastoris and P. angusta have notably been improved, they are still insufficient to be used for commercial purposes and further research is necessary in this context. Interestingly, a non-glycosylated form of recombinant bovine FSH produced in a bacterial expression system (E. coli) showed to be able to stimulate ovarian development in rats [54], emerging as a promising alternative to be further explored.

Luteinizing hormone (LH) and chorionic gonadotropin (CG) In addition to stimulating ovulation in females, along with FSH, LH stimulates the following development of the corpus luteum. In males, $\mathrm{LH}$ is responsible for testosterone secretion in the testes by the Leydig cells, which in turn stimulate spermatogenesis in Sertoli cells. On the other hand, CG supports embryo implantation and pregnancy $[20,55]$. In horses, both LH and CG $\beta$ subunit derive from the same gene, whereas in primates the two gonadotropins are derived from different genes although they share $80 \%$ of their amino acid sequence [55]. CG $\beta$ and LH $\beta$ subunits differ only in the length of their carboxyl terminal regions. The CG has a longer region because of a peptide called carboxyl terminal peptide (CTP) that provides the CG with more glycosylation places and prolong CG half-life by reducing its renal clearance [56]. These extra glycosylation sites have been fused to FSH [6, 19, 32-34] and LH [21, 24, 57-59], which do not naturally contain this sequence, to achieve long-acting hormones. This allowed the reduction in the number of injections for superovulation treatments [13, $36,40]$. Interestingly, given the similarities between the LH and CG, both hormones bind to the LH receptor.

Recombinant LH commercially-available used for animal reproduction purposes is also being produced in $\mathrm{CHO}$ cells (Table 1). As an example, the single-chain EquiPureLH (Venaxis) was used in mares in combination with EquiPureFSH for superovulation treatment [32], or in combination with a pituitary FSH (eFSH; Bioniche Animal Health) to study their effect in follicle and oocyte development [60]. Also, LH has been administered in mares as a model to treat the luteinizing unruptured follicle syndrome in humans [61]. Furthermore, the humanindicated Luveris (hLH; Merck) has been used for early embryonic development treatments in rabbits [62] combined with Gonal-F (see the FSH section), and in mice [63] combined with Pregnyl (hCG; Organon) (Table 1).

Both dimer- [64, 65] and single-chain forms [21, 24, $57-59,66,67]$ of LH and CG have been studied in CHO expression system. Also, human recombinant CG was obtained by $\mathrm{CHO}$ cell expression for the construction of a chimera hCG-boCTP used to study the potential of a CTP-like sequence present but not expressed in the $\beta$ subunit of bovine (among other mammal species) LH [68].

Insect cells have been chosen as an alternative to the expensive $\mathrm{CHO}$ cells, for the recombinant equine $\mathrm{LH}$ and CG production [23, 69, 70] (for a review see [71]). Moreover, $K$. pastoris has been explored to produce recombinant human LH (hLH) and CG (hCG). Gupta et al. already described hCG production in 1999 [72] and some years later other authors successfully produced both hCG [73, 74] and hLH [74] in K. pastoris. Although the hLH expressed by $K$. pastoris showed to be less glycosylated and to have less affinity for the receptor than that naturally expressed in pituitary, it was fully active [74]. Gonadotropins from fish have also been produced in $K$. pastoris, showing the capacity to stimulate steroidogenesis in tilapia $[27,75]$. E. coli-derived hCG $\beta$ was obtained for the first time in 1994 by Huth and coworkers [76]. Briefly, the $\beta$ subunit of this hormone was recovered from purified and solubilized inclusion bodies (IBs), and refolded in vitro to conduct structural and biological studies. After dimerization with a urinary hCG $\alpha$ subunit, the resulting hormone activated ovulation in vivo in rats although its $\beta$ subunit could not be glycosylated by $E$. coli. Thus, this study showed that it is possible to produce biologically-active hormones in a prokaryotic organism, which lacks the capacity to introduce post-translational modifications. In this context, Mukhopadhyay et al. also produced hCG $\beta$ in E. coli for vaccination purposes [77]. This, together with the fact that other hormones, such as growth hormones from different origins have been broadly studied in this recombinant system (buffalo [78], caprine [78], bovine [79], ovine [80] and porcine [81]), showing activities equivalent to those found in natural hormones, suggests that $E$. coli has a bold potential in this field. Although, thus far, mammalian cells have been 
the gonadotropin producers per excellence [13, 27], articles published show that microbes can be used as a real alternative for the production of biologically active CG and $\mathrm{LH}$ through economic and facile processes [36-39, $49,67,70]$.

\section{Inhibin}

During the ovarian cycle, inhibin (which belongs to the TGF $\beta$ superfamily) is mainly secreted by the large developing follicles causing the atresia of the smaller ones [82, 83]. Its secretion in response to increasing levels of FSH in the gonads triggers a negative feedback to the anterior pituitary lowering FSH circulating levels. Therefore, inhibin regulates follicle development and ovulation rates in females, and spermatogenesis in males.

Yan et al. have extensively reviewed inhibin effects (and of its neutralization) on follicle and embryo development [84]. Superovulation treatments with exogenous gonadotropins result in increased numbers of developing follicles, which in turn lead to inhibin concentration rise in plasma [85] and a quantitatively and qualitatively reduced oocyte and embryo development [86]. Consequently, an immunization practice against inhibin, combined with a conventional superovulation protocol, has proven to enhance the quality of the resulting embryos both in vitro and in vivo [87-89]. This immunization has been achieved through the administration of exogenous inhibin leading to antibody production against this glycoprotein.

From a research perspective, recombinant inhibin or its $\alpha$ subunit used in a wide number of studies has been produced in bacteria, and more specifically in E. coli [90]. In this context, genetic engineering has been used to improve inhibin production in E. coli [91]. However, in many other cases inhibin has been produced in mammalian cells [16, 92]. Importantly, recombinant inhibin has been used as an antigen for the immunization against endogenous inhibin in hens [93, 94], cockerels [95], heifers [87, 89, 96], water buffaloes [88], guinea pigs [97], goats [98], and sheep [99-102]. Only in a minority of cases, the recombinant inhibin $\alpha$ subunit used is obtained synthetically [103-106] or purified from follicular fluid [107]. Thus, the production of inhibin, also known as the "superovulatory vaccine", has been extensively studied in recombinant bacteria. Although currently inhibin has not been marketed, the research done with this hormone is promising.

\section{Recombinant fibrolytic enzymes}

The efficiency of plant cell wall digestibility by endogenous enzymes in animals is low. Basically, most nonstarch polysaccharides components present in the animal feed are indigestible by mammalian enzymes, which precludes a full recovery of the nutritional value of the diet. Furthermore, a fraction of the digestible nutrients (i.e., sugars, starch, fat, protein) becomes undigestible because are wrapped by non-starch polysaccharides $[108,109]$. Thus supplementation of diets with exogenous enzymes to enhance animal performance has been a practice extensively used for decades to increase feed conversion rate (proportion of growth relative to the amount of feed consumed). Initially, fibrolytic enzymes were used essentially in non-ruminant animals (pigs and poultry), since it was believed that rumen proteases and ruminal microorganisms were able to efficiently degrade pectans, glucans, xylan, and cellulose. However, digestibility values in ruminants range between 35 and $65 \%$, being widely accepted that the addition of fibrolytic enzymes in ruminant diets can notably increase feed conversion.

Enzymes used can be obtained from organisms able to naturally synthesize them such as fungi or bacteria [110, 111]. However, the obtained products contain an important fraction of impurities, being in many cases a mixture containing different interfering enzymatic activities. In this context, recombinant technology has been playing an important role since different fibrolytic enzymes can be produced separately using both homologous and heterologous protein expression hosts [110-115]. Some of these enzymes ( $\beta$-glucanases, xylanases, mannanases, pectinases, and galactosidases) are used to specifically degrade feed components resistant to endogenous enzymes. Other enzymes, like phytases, are applied to inactivate antinutritional factors. Moreover, in some cases the supplementation with endogenous enzymes that are not produced at sufficient levels by the animal, such as proteases, lipases, and amylases are also used (Table 2). In general terms, unlike other applications previously mentioned, these enzymes are partially purified and commercialized as cellular extracts or culture supernatants that are directly used for feeding purposes, and thus commercial enzymes do not confer a single pure enzymatic activity (Table 1). However, some purification steps are required to eliminate any possible residues of genetically modified DNA and/or undesirable fermentation residues in the final product, but these purification processes are relatively simple.

Thus, although nowadays an important number of enzymes are commercially available for animal nutrition to improve animal productivity and the efficacy of utilization of natural resources, the development of optimized strategies for the production of fibrolytic enzymes is highly desirable. In this line, an extensive array of microorganisms, including bacteria (E. coli, Bacillus subtilis, and Bacillus licheniformis), yeast (K. pastoris), and fungus (Trichoderma reesei and Aspergillus niger), are 
Table 2 Marketed carbohydrases

\begin{tabular}{|c|c|c|c|c|}
\hline Name & Activity & Cell factory & Animal & Company \\
\hline \multicolumn{5}{|l|}{ Xylanases } \\
\hline Econase XT & Xylanase & Trichoderma reesei (GMO) & Poultry and pigs & ABVista \\
\hline Danisco xylanase & Xylanase & Trichoderma reesei (GMO) & Poultry and pigs & Danisco Animal Nutrition \\
\hline Hostazym X & Xylanase & Trichoderma citrinoviride (not GMO) & Poultry and pigs & Huvepharma \\
\hline Porzyme ${ }^{\circledR} 9300$ & Xylanase & $\begin{array}{l}\text { Trichoderma longibrachiatum (not } \\
\text { GMO) }\end{array}$ & Poultry and pigs & Danisco Animal Nutrition \\
\hline Ronozyme WX & Xylanase & Aspergillus oryzae (GMO) & Poultry and pigs & DSM-Novozymes \\
\hline Belfeed B 1100 MP & Xylanase & Bacillus subtilis (GMO) & Poultry and pigs & Beldem \\
\hline Xylamax ${ }^{\mathrm{TM}}$ & Xylanase & NA & Poultry & $\mathrm{BRI}$ \\
\hline \multicolumn{5}{|l|}{ Beta-glucanases } \\
\hline Econase ${ }^{\circledR} \mathrm{GT}$ & $\beta$-Glucanase & Trichoderma reesei (GMO) & Poultry and pigs & ABVista \\
\hline Hostazym C & $\beta$-Glucanase & Trichoderma citrinoviride (not GMO) & Poultry and pigs & Huvepharma \\
\hline \multicolumn{5}{|l|}{ Amylases } \\
\hline $\begin{array}{l}\text { Roxazyme }^{\circledR} \\
\text { Rumistar }^{\text {TM }}\end{array}$ & a-Amylase & Bacillus licheniformis (GMO) & Dairy cows & DSM-Novozymes \\
\hline \multicolumn{5}{|l|}{ Multienzyme } \\
\hline Avemlx ${ }^{\circledR} X G 10$ & Xylanase, $\beta$-glucanase & Trichoderma reseei (not GMO) & Poultry and pigs & Aveve Biochem \\
\hline Roxazyme ${ }^{\circledR} \mathrm{G} 2$ & Xylanase, $\beta$-glucanase & Trichoderma reseei (not GMO) & Poultry and pigs & DSM-Novozymes \\
\hline Axtra ${ }^{\circledR} X B$ & Xylanase, $\beta$-glucanase & Trichoderma reesei (GMO) & Poultry and pigs & Danisco Animal Nutrition \\
\hline Axtra ${ }^{\circledR}$ XAP & Xylanase, amylase, protease & Trichoderma reesei (GMO) & Poultry and pigs & Danisco Animal Nutrition \\
\hline Avemlx ${ }^{\circledR} 02$ CS & Xylanase, $\beta$-glucanase, pectinase & $\begin{array}{l}\text { Trichoderma reseei (not GMO), Aspergil- } \\
\text { lus aculeatus (not GMO) }\end{array}$ & Poultry and pigs & Aveve Biochem \\
\hline Avizyme $^{\circledR}$ & Xylanase, amylase, protease & $\begin{array}{l}\text { Trichoderma reesei (GMO), Bacillus } \\
\text { amyloliquefaciens (GMO), Bacillus } \\
\text { subtilis (GMO) }\end{array}$ & Poultry & Danisco Animal Nutrition \\
\hline Endofeed & Xylanase, $\beta$-glucanase & Aspergillus niger (not GMO) & Poultry & GNC Bioferm \\
\hline Natugrain ${ }^{\circledR}$ & Xylanase, $\beta$-glucanase & Aspergillus niger (GMO) & Poultry & BASF \\
\hline Natuphos ${ }^{\circledR}$ combi & Xylanase, $\beta$-glucanase, phytase & Aspergillus niger (GMO) & Poultry and pigs & BASF \\
\hline Agal Pro BL & Alfa-galactosidase, $\beta$-glucanase & $\begin{array}{l}\text { Aspergillus niger (not GMO), Saccharo- } \\
\text { myces cerevisiae (GMO) }\end{array}$ & Poultry & Biocon \\
\hline Amylofeed & Xylanase, $\beta$-glucanase, amilase & $\begin{array}{l}\text { Aspergillus niger, Aspergillus oryzae (not } \\
\text { GMO) }\end{array}$ & Pigs & GNC Bioferm \\
\hline Porzyme ${ }^{\circledR} 9100$ & Xylanase, $\beta$-glucanase & $\begin{array}{l}\text { Trichoderma longibrachiatum (not } \\
\text { GMO) }\end{array}$ & Pigs & Danisco Animal Nutrition \\
\hline Xybeten $^{\circledR}$ & Xylanase, $\beta$-glucanase, cellulase & $\begin{array}{l}\text { Trichoderma longibrachiatum (not } \\
\text { GMO) }\end{array}$ & Poultry and pigs & Biovet \\
\hline Ronozyme ${ }^{\circledR}$ VP & Pectinase, $\beta$-glucanase & Aspergillus aculeatus (not GMO) & Poultry and pigs & DSM-Novozymes \\
\hline Rovabio ${ }^{\circledR}$ Excel & $\begin{array}{l}19 \text { enzymes (xylanases, } \beta \text {-glucanase, } \\
\text { and cellulases with other enzyme } \\
\text { activities) }\end{array}$ & Penicillium funiculosum (not GMO) & Poultry and pigs & Adisseo \\
\hline Ronozyme ${ }^{\circledR}$ Multigrain & Xylanase, $\beta$-glucanase & NA & Poultry and pigs & DSM-Novozymes \\
\hline Ronozyme A & Amilase, $\beta$-glucanase & NA & Poultry and pigs & DSM-Novozymes \\
\hline Cibenza ${ }^{\circledR}$ CSM & Xylanase, $\beta$-glucanase, a-galactosidase & NA & Poultry and pigs & Novus International \\
\hline
\end{tabular}

Xylanases, $\beta$-glucanases and a-amylases have one declared enzymatic activity, while in some cases some secundary activities are also present in the product $N A$ information not available

being explored for the production of enzymes with interest in the feed industry. All the strategies that are being explored aim at designing fibrolytic enzymes that meet the industry requirements, which include high production yields, low production costs, easiness to scale-up, high catalytic efficiency, and improved stability under different temperature and $\mathrm{pH}$ conditions. This includes the use of genetic and protein engineering approaches to produce highly-active enzymes, and variants with an increased resistance to temperature and proteolysis (in many cases derived from extremophile microorganisms), ultimately resulting in a greater stability in the 
gastrointestinal tract. Research in this field is still underway and every year optimized processes and new products are developed and a large number of articles on this topic are published. This is particularly important considering that the global feed market is continuously growing. In particular, feed market is dominated by carbohydrases (being xylanases and beta-glucanases the most important) and phytases.

\section{Carbohydrases: xylanases, beta-glucanases, and amylases}

Xylanases can break down xylan, which is a major polysaccharide of hemicelluloses present in plant cells and in some algae. Thus, xylanases are widely used in animal feed to degrade complex hemicelluloses. Most of the xylanases used in feed industry for enzymatic treatment of animal feed are derived from those naturally produced in fungi [116-118]. Some examples are Danisco xylanases (Danisco Animal Nutrition) and Econase XT (ABEnzymes) that are produced in $T$. reesei, whereas Prozyme 9300 (Danisco Animal Nutrition) is produced in Trichoderma longibrachiatum, Ronozyme WX (DSMNovozyme) in Aspergillus oryzae, and Hostazym X (Huvepharma) in Trichoderma citrinoviride (Table 2). There is also a commercial example of a recombinant xylanase produced in bacteria (Belfeed B 1100 MP, Beldem, B. subtilis) (Table 2).

However, as previously described, most of these commercial products are not pure enzymes, but a complex fermentation product that in some cases contains a mixture of different enzymatic activities that may have a synergistic effect (Table 2). In many cases, xylanase is combined with $\beta$-glucanase, whereas in others amylase, protease, pectinase, phytase, and/or $\alpha$-galactosidase are also present in the mixture (Table 2).

$\beta$-Glucanases are enzymes capable of breaking down cellulose and have been used in poultry, pigs, ruminants, and fish since early 1980 to facilitate the bioconversion of cellulose to animal products (Table 2). On the other hand, $\alpha$-amylases are used in dairy cow nutrition to increase feed efficiency and milk production [119-123]. The most widely used is Roxazyme ${ }^{\circledR}$ RumistarTM (DSMNovozyme), which has been produced in a geneticallymodified B. licheniformis (Table 2).

Given the importance of xylanases, $\beta$-glucanases, and $\alpha$-amylases to improve the nutritional value of nonstarch polysaccharides, and the increasing demand of more stable, highly-active, and non-expensive carbohydrases, different microbial hosts have been explored for their production. Although commercial carbohydrases are mainly derived from fungi, research in this field focuses in the development of bacterial and yeast-based production systems [124]. This is particularly evident for xylanases.
Considering that, in many cases, glycosylation is necessary to obtain functional and stable xylanases [125, 126], yeasts appear as the most promising heterologous expression host for their production as an alternative to fungi. Besides, some yeast have been accredited with the generally recognized as safe (GRAS) status by the American Food and Drug Administration (FDA), which brings additional value to this expression system. Altogether these advantages make yeast, and more specifically $K$. pastoris, the most widely used microorganism for xylanase production (extensively reviewed by [126]). Briefly, $K$. pastoris has been explored for the production of xylanases from T. reesei [127], Aspergillus sulphureus [128], A. niger [129, 130], and Streptomyces sp. S38 [131], among others [126]. Albeit at a lesser extent, S. cerevisiae has also been studied for the production of fungal xylanases [112, 132, 133]. Different enzymes in different yeast-based cell factories have been evaluated under diverse production conditions aiming to optimize enzyme production yields [133]. $\mathrm{Li}$ et al. and $\mathrm{Fu}$ et al., for instance, improved the production efficiency of the enzyme simply using an optimized sequence with the appropriate codon usage $[128,131]$. On the other hand, Fang and collaborators described that $x y l B$ gene overproduced is not glycosylated, but it is still fully active and highly stable under different conditions [130]. Other fungal xylanases have also been shown to be non-glycosylated enzymes [118]. In line with this observation, different groups have described the production of catalytically-active eukaryotic xylanases in E. coli $[134,135]$. Thus, E. coli, although to a lesser extent due to their lack of secretion system, has also been used to study different bacterial xylanases [136, 137]. Alternatively, other Gram-positive bacteria, such as Lactobacillus spp. and B. subtilis, also classified as GRAS organisms, have been used as cell factories for xylanase production purposes. Interestingly, these Gram-positive bacteria have a dual effect, since they are explored as probiotics to enhance gut health, but at the same time they are able to secrete recombinant enzymes of interest such as xylanases [138, 139]. In some cases, strategies to anchor xylanases in the bacterial cell wall have been explored [140]. Lastly, filamentous fungal expression systems (mainly Aspergillus spp. and Trichoderma spp.) have been also extensively studied for xylanase expression (reviewed in [116]) and, in fact, they are, as previously mentioned, the microorganism behind some products commercially available (Table 2). Other fungi such as Thermoascus aurantiacus have also been explored as potential cell factories for xylanase production [141]. Although fungi produce high levels of xylanase, they have two important limitations for industrial application, a reduced yield in fermenter conditions, and poor secretion efficiency. 


\section{Phytases}

Non-ruminant intestinal microorganisms, in contrast to what occurs with ruminal bacteria, are unable to degrade phytate from plant-derived feedstuffs [142]. This is particularly important considering that phytate is the major source of phosphorous in animal diets. Thus, traditionally, the main phosphorous source in poultry, swine, and fish diets came from the inorganic phosphates via dietary supplementation. However, the excretion of excess phosphorous by animals fed supplemented diets was accumulated in the soil and water, creating a major environmental problem $[143,144]$. This challenge was minimized with the commercialization in 1991 of the first recombinant phytase, which allowed avoiding the supplementation of diets with inorganic phosphorous and, consequently, decreasing phosphorus pollution in animal waste [145].

Since the development of the first commercial phytase product (Natuphos, BASF), others have been launched in the market and are nowadays available [113] (Fig. 1). Phytases that are available today are produced recombinantly in microbes including fungi ( $T$. resei, A. niger, and $A$. oryzae) and yeast (Saccharomyces pombe and $K$. pastoris) (Fig. 1) and are widely used in diets for nonruminant animals.

The market of feed enzymes and, more specifically of acidic phytases, has significantly grown in the last decades and its demand is estimated to continue growing in the next years. Phytases are enzymes with a large market ( $60 \%$ of the total feed enzyme market), which combine the capacity to improve feed efficiency with the advantage of reducing the phosphorus pollution. Due to the important phytase applicability in animal feeding, several groups are working on the design, production and characterization of phytases with optimized properties. Haefner et al., Lei et al., and Rao et al. have published extensive reviews describing all the advances in the

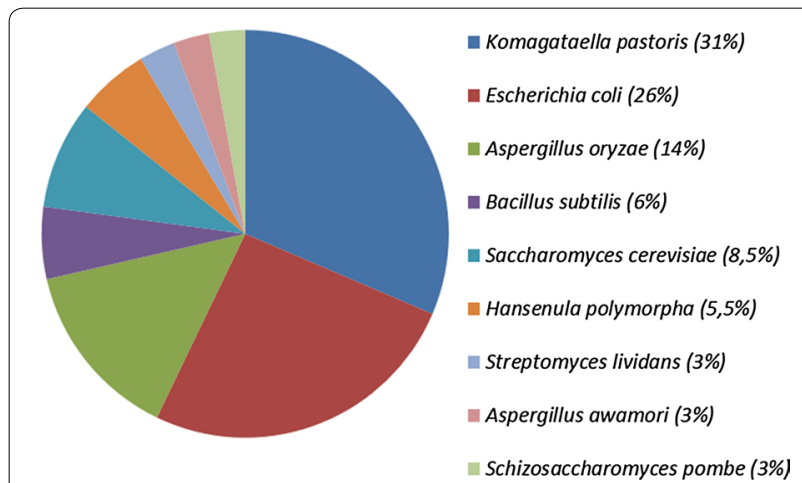

Fig. 1 Recombinant cell factories (expressed in percentages) used for the production of commercial phytases production of phytases using recombinant cell factories $[113,142,146]$.

Research on phytase synthesis has used fungi, bacteria, yeast, and plants [113, 142, 146-148] (Fig. 2). Among fungi, the genus Aspergillus has been the most widely explored for the isolation of phytases with interesting properties. Besides, different species from the genus Bacillus, as well as some Lactobacillus and E. coli have been deeply studied [147]. Although phytases were initially isolated from their natural origin, it is widely accepted that the levels of production in such wild type strains is too low. In this context, recombinant DNA technology has allowed to make a major step toward the production of phytases at high production levels using optimized cell factories. Summarizing, among all the recombinant cell factories reported in the literature used for the production of phytases, K. pastoris and E. coli appear as the most widely used microbial factories for research purposes, whereas $A$. oryzae is the preferred option among fungi (Fig. 2).

Currently, phytase research is still focused on the identification of new phytases, but more importantly there is a clear trend towards the optimization of key properties of the already described enzymes. For the development of a new generation of phytases as feed additives, genetic and protein engineering play a key role, since they are powerful tools to develop tuned phytase variants.

Considering that the action of phytases takes place in the stomach, one of the most important requirements for phytases is a high resilience at low $\mathrm{pHs}$ and resistance to proteolytic degradation. Aside from this high stability to the upper digestive tract conditions, phytases used to increase animal feed efficiency must resist high temperatures to cope with the conditions of the feed pelleting process. Obviously, it is also necessary to develop enzymes with a good catalytic efficiency and produced through cost-effective production processes [113]. Aiming to produce modified phytases with optimal

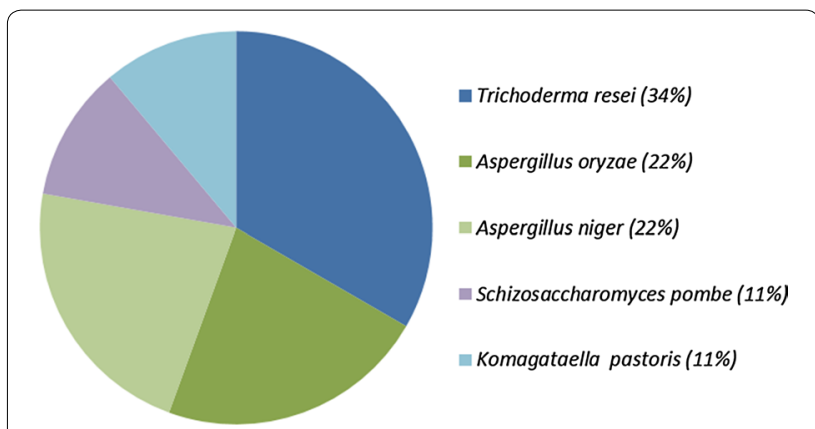

Fig. 2 Recombinant cell factories (expressed in percentages) used for the production of phytases described in research articles 
properties, different expression systems are being evaluated, using the sequence of phytases from different sources as starting point for further improvements. It is important to note that different expression systems (combined with phytases from different origins) produce enzymes with different biophysical and biochemical properties. For instance, the molecular mass greatly depends on the phytase origin and on the glycosylation pattern. Because bacterial phytases do not have posttranslational modifications, they are easier to produce and thus have an important advantage over those from other origins. Thermostability, catalytic performance, substrate specificity, and stability at acidic $\mathrm{pHs}$ are greatly influenced by both heterologous system and origin. Thus far, although important advances have been achieved in this field, no enzyme with all the optimal parameters has been developed [149]. Among all those that have been studied, enzymes derived from extremophylic organisms such as Rhizomucor pusillus, Thermomyces lanuginosus, Aspergillus fumigatus, Peniophora lycii, Agrocybe pediades, and Ceriporia sp., appear as the most promising candidates [150-154]. Resolution of the crystallographic structure of some phytases allows a better understanding of this enzyme, providing a good starting point to optimize the protein engineering process. Besides, sophisticated optimization of the condition for the growth processes are also contributing to maximize titers of the variant of interest $[142,155]$.

In short, fibrolytic enzymes extracted from their natural sources have a low productivity yield and poor thermal and $\mathrm{pH}$ stability. In this context, all the efforts have focused on the development of highly active enzymes able to support extreme environments and resistant to proteases. Importantly, this needs to be done through cost-effective and high-production processes to make the new enzymes a real alternative to the existing commercial ones. In this context, bacteria and yeast represent promising alternative microbial cell factories for the production of these enzymes [124].

\section{Recombinant proteins for prevention and therapy Recombinant antibodies}

The use of passive immunization (administration of antibodies) for the control of infectious disease has been recognized as a successful approach in the modern production of a wide range of animals, including pigs, cattle, sheep, goats, poultry, and fish [156]. In contrast to vaccination or active immunization, administration of immunoglobulins establishes instant immunity and provides short-term protection with no induction of immunological memory. With multifactorial infectious diseases, especially those that have proven hard to control by vaccination, the potential of passive immunization is high.
Moreover, this type of therapy may be considered as an alternative to antibiotics, whose use is starting to be limited due to concerns about potential development of antibiotic-resistant bacteria.

During the last decade, the development of recombinant antibody technologies has offered the possibility for developing highly specific pathogen-specific antibodies using a cost-effectiveness and reproducible technology [157]. Some studies have demonstrated the success of using recombinant antibodies in animal production. Transmissible gastroenteritis virus (TGEV) is a positivestrand RNA virus of the family Coronaviridae, infecting both enteric and respiratory tissues of pigs and causing a mortality rate close to $100 \%$ when newborn pigs are infected [158]. Single-chain fragments $(\mathrm{scFv})$ obtained by joining the light- and heavy-chain variable regions (VL and $\mathrm{VH}$ ) from a monoclonal antibody (mAb) reconstitute the original $\mathrm{VL}-\mathrm{VH}$ association and retain the binding specificity of the original $\mathrm{mAb}$ in a single polypeptide [159]. To improve the affinity of monovalent $\mathrm{scFv}$, dimeric single-chain mini-antibody molecules, named minibodies or SIPs (small immunoproteins), have been generated by connecting an scFv to the dimerizing domain of immunoglobulin heavy chains. These recombinant proteins are efficiently assembled and secreted in dimeric form by mammalian cells. In vivo protection experiments on newborn piglets have demonstrated a strong reduction of virus titers in infected tissues of animals orally treated with TGEV-specific SIPs [160].

On the other hand, available vaccines for bovine herpes virus 1 (boHV-1), which causes respiratory and genital diseases in cattle, do not confer adequate protection. Koti et al. developed a bovine $\mathrm{scFv}$ that has a proven specificity and in vitro neutralization activity against BoHV-1 [161]. K. pastoris was selected over bacterial expression systems available, since yeast has protein processing and post-translational modifications similar to those present in higher-order eukaryotes as well as providing high recombinant protein yield under the influence of $A O X 1$ promoter. In a posterior study, the authors demonstrated that scFvs against BoHV-1 with a short linker (2 amino acids) were capable of assembly into functional multimers that conferred high avidity, resulting in increased virus neutralization in vitro compared with that of monovalent scFv [162]. These studies need to be further expanded to experiments involving virus challenges to determine the efficacy of passive protective immunity provided by bovine scFv. However, since the virus neutralization ability of the $\mathrm{scFv}$ in vitro was comparable to the parental mAb against BoHV-1, which reduces mortality in rabbits infected with BoHV-1, there is a future potential to be used in infected animals, to treat semen preventing the spread of BoHV-1 infection, or even by 
local application to treat infectious pustular vulvovaginitis caused by BoHV-1.

Another example is the foot-and-mouth disease virus (FMDV), which is a contagious viral disease that affects cloven-hoofed animals such as cattle, swine, and sheep with a potential for rapid spread. Emergency treatment by passive immunization can be used as an important control measure for FMDV outbreaks in FMDV-free regions such as the European Union. Harmsen et al. produced recombinant llama single-domain antibody fragments (VHHs) using recombinant strains of $S$. cerevisiae to confer rapid protection against FMDV by passive immunization in pigs [163].

VHHs have a number of advantages for therapeutic applications because they are well produced by microorganisms, have a high physicochemical stability and are well-suited for the construction of genetic fusions of several VHH domains [164]. Moreover, it is important to note that in that study no immunogenicity of VHHs was detected in treated pigs, which is an important aspect because passive immunotherapy can be complicated by the induction of an antibody response against the administered heterologous therapeutic recombinant antibody, especially when such antibodies are administered repeatedly.

From our knowledge, the only case of recombinant antibody produced thus far in E. coli as a potential therapy for animal production is related to the treatment of intrammamary infections. Bovine intrammamary infections are an important disease that causes large economical losses in the dairy industry and where passive immunization could be an interesting alternative, especially to treat infections such as those caused by Staphylococcus aureus, where vaccines do not confer adequate protection and the conventional antibiotic treatments have a limited success rate. Wang and collaborators constructed a recombinant $\mathrm{scFv}$ against fibronectin-binding protein A (FnBPA) and clumping factor A (ClfA), two important virulence factors in S. aureus infection [165]. However, future in vivo studies of the functionality of these scFvs are needed to confirm the potential of such scFvs.

\section{Other therapies}

Cytokines are small molecules, which act as intercellular communication signals and play a role in various aspects of the differentiation and maturation of immune system cells and the host response to infection. Although this network is complex, there is already available information on the role of specific cytokine in the modulation of the immune system in livestock as a preventive strategy of diseases or even controlling metabolic and physiological processes. There are many in vivo studies testing targeted recombinant cytokines that stimulate the immune system to fight intramammary infections during both the lactation and the dry (the last 2 months of pregnancy, when the cow does not lactate) periods in dairy cows. Intramammary infusion of recombinant IL-2, IFN $\gamma$, IL- $1 \beta$, and IL- 8 in the mammary gland of lactating cows have been shown to offer protection against $S$. aureus or E. coli infections [166-169]. Moreover some recombinant cytokines such as IL-8 and recombinant bovine granulocyte-macrophage colony stimulating factor (rboGMCSF) [170] have been able to foster the involution of the mammary gland during the dry period (a period where tissue of mammary gland is involuted and regenerated in the preparation for the subsequent lactation).

Dairy cows often experience decreased immune function around the time of calving, typified by impaired polymorphonuclear neutrophil (PMN) function and increased incidence of disease. Subcutaneous injections of recombinant bovine granulocyte colony-stimulating factor covalently bound to polyethylene glycol (PEG rbGCSF) dramatically increased circulating numbers of PMN [171]. Other applications concern to the improvement of reproductive performance of production animals using

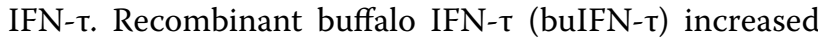
in vitro buffalo blastocyst production rate [172] although intrauterine administration of liposomized bovine IFN- $\tau$ had no effect on the length of the estrous cycle and the lifespan of the corpus luteum in dairy cows [173]. However, Shirasuna et al. found that recombinant IFN- $\tau$ was associated to greater amounts of protein, IL-8, and neutrophils in the corpus luteum of pregnant cows [174]. Lastly, supplementing recombinant porcine leukemia inhibitory factor (poLIF) in the in vitro maturation medium can improve oocyte maturation [175].

The ability of IL-3 to stimulate the development of eosinophils makes it a particularly important candidate for therapeutic use to protect against parasites. Morris et al. demonstrated that in vivo administration of poIL-3 induced a significant increase in the number of eosinophils in the blood of pigs [176]. In a similar context, chicken IFN- $\gamma$ (chIFN- $\gamma$ ) demonstrated reductions in intracellular sporozoite development in vitro without affecting sporozoite invasion of host cells. Furthermore, chickens treated with recombinant chIFN- $\gamma$ showed decreased oocyst production and significant improvement in body weight gain following an Eimeria acervulina challenge infection $[177,178]$.

All these cytokines have been produced in several recombinant systems such as mammalian cells in the case of bovine IFN- $\mathrm{\tau}$ (boIFN- $\mathrm{r}$ ) [173], bovine IL-2 (boIL2) [167], porcine IL-3 (boIL-3) [176], poLIF [175], and chIFN- $\gamma$ [177]. Insect cells have been chosen for the production of chIFN- $\gamma$ [177], Brevibacillus choshinensis for boIL-8 [168], K. pastoris for boIL-2, IFN- $\gamma$, and GM-CSF 
[170] and E. coli for buIFN-t [172], boIFN-t [174], and chIFN- $\gamma[178]$.

Also in the context of the immune system modulation, the mammary serum amyloid A (M-SAA3) protein (an acute phase protein from the mammary gland) has been produced recombinantly in E. coli [179] and proposed as an immunostimulator of the mammary gland to fight against infections and enhance mammary involution during the dry cow period. The administration of M-SAA3 triggers an inflammatory response, the maturation of dendritic cells, and reduces the infection of mammary epithelia by pathogens such as $S$. aureus. Furthermore, relevant functions have been demonstrated in mammary function of dry cows such as the increase in neutrophil recruitment and of some key effectors of tissue involution such as metalloproteinase 9 (MMP-9) [180].

In summary, a new era of recombinant proteins, mostly key effectors in the immune system, opens the possibility to modulate physiological processes and prevent infections reducing the use of antibiotics in livestock and paving a safer and more productive future.

\section{Future perspectives}

The use of genetic and protein engineering techniques have led to a significant progress in animal production and it is starting to have a commercial impact in this field. Nowadays it is possible to design tailor-made sequences of enzymes, which in some cases combine specific properties of different enzymes in one molecule to obtain an optimal functional protein [181]. On the other hand, this technology allows the production of recombinant hormones through cost-effective processes using microbial cells as production hosts. In addition to this, novel strategies such as those based on passive immunization are gaining ground due to the broad range of possibilities that recombinant protein production offers. In this context, although important efforts have been done toward the minimization of recombinant protein production costs, currently, much remains still to be achieved. Cost effectiveness is particularly important in the context of animal production, where marginal returns are tight. Currently, the main restriction for the application of recombinant products in animals is still the cost associated to the production processes. Overcoming this bottleneck requires developing alternative strategies to further reduce the production costs of recombinant products and there is a wide range of unexplored strategies to improve recombinant production of proteins of interest for animal production.

The use of bacterial strains with an oxidizing cytoplasm, for example, represents a good approach to improve the production yields of proteins containing disulfide bonds. In this line of work, the development and optimization of production protocols for both bacteria and yeast and the use of genetic engineering to obtain proteins with improved stability is useful. On the other hand, though yeast and bacteria are being explored as alternatives for the production of many proteins of interest, the catalogue of other promising microorganisms for this purpose is limited. Lactic acid bacteria (LAB) are an attractive alternative for recombinant protein production, since they are GRAS organisms able to produce difficult-to-express proteins [182, 183]. Even though these microorganisms have been explored in some cases for animal production purposes, especially for the production of fibrolytic enzymes, broadening their field of application would be highly convenient. They do not only show the ability to produce recombinant proteins, but they also have interesting properties as probiotics. Besides, they are able to efficiently secrete the protein of interest, which reduces the purification costs of the product of interest, and also are used for surface display purposes [184]. Interestingly, surface display, which allows to naturally anchor the enzyme of interest to the cell envelop once it is produced by the recombinant cell, has already been proven to improve the stability of an endoglucanase produced in K. pastoris [185].

However, it is also necessary to think beyond these classical strategies and make use of novel approaches, such as nanobiotechnology, which has been explored in other fields of research. Considering that recombinant proteins are poorly used in animal production due to their normally high associated costs, new protein formats need to be explored. Among them, inclusion bodies (IBs), which are a low-cost, highly stable, and functional protein nanoparticles mainly containing the protein of interest overproduced in a recombinant system, represent a new and appealing protein format [186, 187]. Production of recombinant proteins as IBs allows the production of any protein of interest through a much more affordable process [186-189], which could open a wide range of possibilities in animal science. Thus far, in the context of animal production, IBs from E. coli have only been used as a source of protein. For that, as previously described, solubilization protocols using denaturants such as urea or guanidinium chloride followed by renaturation processes have been used to obtain properly folded and functional soluble proteins [76, 190, 191]. Nevertheless, IBs have never been explored as protein-based nanoparticles for animal reproduction, enhancers of feed efficiency, or treatment purposes, with only one exception. A recent article described for the first time that IBs formed by cytokines can successfully be used as a prophylactic measure, showing that zebra fish treated with IBs are protected against a lethal infection [192]. In the same way that cytokines have been successfully produced as IBs 
for prevention purposes in fish, other proteins of interest (hormones, enzymes, and antibodies, among others) or other animal species could also be explored, unfolding enormous possibilities in this field. Contrarily to what has been widely believed, the formation of IBs does not only occur in $E$. coli, but in many other expression systems including yeast [193] and LAB [186, 194], meaning that their production can be conducted in a wide variety of microbial cell factories. Moreover, their size and shape are easily tunable.

Alternatively, protein encapsulation and/or coating could also be interesting nanobiotechnological approaches to increase protein stability, minimize doses and, consequently, reducing costs of proteins of interest for animal production. Nanoemulsions, liposomes, polymersomes, protein nanocapsules, polymeric nanoparticles, and hydrogel nanoparticles are some examples of different nanostructured systems used for protein encapsulation [195-198]. As an example, Diwan and collaborators described the encapsulation of gonadotropin-releasing hormone in polylactic-co-glycolic acid microspheres [199]. In another recent example, the use of gold nanoparticles has been studied to increase the stability and efficiency of a xylanase [200].

In summary, new protein formats such as IBs and encapsulation methods need to be further explored in animal science as attractive alternatives to make recombinant molecules affordable. Molecule stability and functionality can significantly be improved through these strategies.

\section{Conclusions}

Recombinant DNA technology allows modulating protein sequence, which therefore makes it possible to obtain recombinant products with improved properties compared with those isolated from their native hosts. This has helped to make a significant step forward in the development of recombinant products for a wide array of applications, including animal production, as reviewed in the text. A broad catalogue of microbial cell factories is being explored for the successful development of enzymes, hormones, and therapeutic molecules. Nevertheless, to continue advancing in this field of study, it is necessary to make a giant leap towards the use of novel strategies that combined with recombinant technology would allow the development of products with applicability in animal science. In this context, nanotechnology, and more specifically nanostructuration, could play a crucial role in the development of a new generation of recombinant biomolecules with affordable costs for animal industry.

\section{Authors' contributions}

EGF and AA conceived and designed the manuscript. LG, AA and EGF performed the bibliographic research, conceptualized and drafted the manuscript. AB outlined the structure and reviewed the manuscript. All authors read and approved the final manuscript.

\section{Author details}

${ }^{1}$ Department of Ruminant Production, Institut de Recerca i Tecnologia Agroalimentàries (IRTA), 08140 Caldes de Montbui, Spain. ${ }^{2}$ Institució Catalana de Recerca i Estudis Avançats (ICREA), Barcelona, Spain.

\section{Acknowledgements}

We are also indebted to "Serveis de Vigilància Tecnològica" from IRTA for helpful assistance.

\section{Competing interests}

The authors declare that they have no competing interests.

\section{Availability of data and materials}

The datasets supporting the review are referenced within the article.

\section{Funding}

We are indebted to CERCA Programme (Generalitat de Catalunya) and European Social Fund for supporting our research. LG received a pre-doctoral fellowship from INIA (FPI-INIA, MINECO) and EGF is supported by a post-doctoral fellowship from INIA (DOC-INIA, MINECO).

Received: 8 October 2016 Accepted: 26 February 2017

Published online: 04 March 2017

References

1. Rosano GL, Ceccarelli EA. Recombinant protein expression in Escherichia coli: advances and challenges. Front Microbiol. 2014;5:1-17.

2. Saccardo P, Corchero JL, Ferrer-Miralles N. Tools to cope with difficultto-express proteins. Appl Microbiol Biotechnol. 2016;100:4347-55.

3. Itakura K, Hirose T, Crea R, Riggs A, Heyneker H, Bolivar F, Boyer H. Expression in Escherichia coli of a chemically synthesized gene for the hormone somatostatin. Science. 1977;198(4321):1056-63.

4. Bó GA, Mapletoft RJ. Historical perspectives and recent research on superovulation in cattle. Theriogenology. 2014;81:38-48.

5. Diskin M, Austin E, Roche J. Exogenous hormonal manipulation of ovarian activity in cattle. Domest Anim Endocrinol. 2002;23:211-28.

6. Jennings MW, Boime I, Daphna-Iken D, Jablonka-Shariff A, Conley AJ, Colgin M, Bidstrup LA, Meyers-Brown GA, Famula TR, Roser JF. The efficacy of recombinant equine follicle stimulating hormone (reFSH) to promote follicular growth in mares using a follicular suppression model. Anim Reprod Sci. 2009;116:291-307.

7. Liu Y, Tian Y, Zhao X, Jiang S, Li F, Zhang Y, Zhang X, Li Y, Zhou J, Fang F. Immunization of dogs with recombinant $\mathrm{GnRH}-1$ suppresses the development of reproductive function. Theriogenology. 2015;83:314-9.

8. Geary TW, Grings EE, MacNeil MD, De Avila DM, Reeves JJ. Use of recombinant gonadotropin-releasing hormone antigens for immunosterilization of beef heifers. J Anim Sci. 2006;84:343-50.

9. Kim H, Lee Y, Kang SC, Han BK. Recent vaccine technology in industrial animals. Clin Exp Vaccine Res. 2016;5:12-8.

10. Shams $\mathrm{H}$. Recent developments in veterinary vaccinology. Vet J. 2005;170:289-99.

11. Van Kampen KR. Recombinant vaccine technology in veterinary medicine. Vet Clin North Am Small Anim Pract. 2001;31:535-8.

12. Adams TE, Boime I. The expanding role of recombinant gonadotropins in assisted reproduction. Reprod Domest Anim. 2008;43:186-92.

13. Hesser MW, Morris JC, Gibbons JR. Advances in recombinant gonadotropin production for use in bovine superovulation. Reprod Domest Anim. 2011:46:933-42.

14. Cahoreau C, Klett D, Combarnous Y. Structure-function relationships of glycoprotein hormones and their subunits' ancestors. Front Endocrinol (Lausanne). 2015;6:1-14. 
15. Aizen J, Kobayashi M, Selicharova I, Sohn YC, Yoshizaki G, Levavi-Sivan B. Steroidogenic response of carp ovaries to piscine FSH and LH depends on the reproductive phase. Gen Comp Endocrinol. 2012;178:28-36.

16. De Koning WJ, Walsh GA, Wrynn AS, Headon DR. Recombinant reproduction: the importance of gonadotrophic and related hormones in veterinary and human medicine may increase with the adoption of recombinant production methods. Nat Biotechnol. 1994;12:988-92.

17. Murphy BD, Mapletoft RJ, Manns J, Humphrey WD. Variability in gonadotrophin preparations as a factor in the superovulatory response. Theriogenology. 1984;21:117-25

18. Monniaux D, Chupin D, Saumande J. Superovulatory responses of cattle. Theriogenology. 1983;19:55-81.

19. Meyers-Brown GA, McCue PM, Niswender KD, Squires EL, DeLuca CA, Bidstrup LA, Colgin M, Famula TR, Roser JF. Superovulation in mares using recombinant equine follicle stimulating hormone: ovulation rates, embryo retrieval, and hormone profiles. J Equine Vet Sci. 2010;30:560-8.

20. Pierce JG, Parsons T. Glycoprotein hormones structure and function. Annu Rev Biochem. 1981;50:465-95.

21. Grinberg M, Nakav S, Pen S, Dantes A, Braw-Tal R, Amsterdam A, BenMenahem $D$. The configuration of the alpha and beta subunit domains in single-chain bovine LH analogs influences the secretion and steroidogenic response. Mol Cell Endocrinol. 2008;283:83-95.

22. Asraf H, Amsterdam A, Ben-Menahem D. Modulation of the steroidogenic related activity according to the design of single-chain bovine FSH analogs. Gen Comp Endocrinol. 2015;216:171-81.

23. Legardinier S, Poirier JC, Klett D, Combarnous Y, Cahoreau C. Stability and biological activities of heterodimeric and single-chain equine LH/ chorionic gonadotropin variants. J Mol Endocrinol. 2008;40:185-98.

24. Rutigliano HM, Adams BM, Jablonka-Shariff A, Boime I, Adams TE. Effect of single-chain ovine gonadotropins with dual activity on ovarian function in sheep. Reproduction. 2014;148:129-36.

25. Butnev VY, Butnev VY, May JV, Shuai B, Tran P, White WK, Brown A, Hall AS, Harvey DJ, Bousfield GR. Production, purification, and characterization of recombinant hFSH glycoforms for functional studies. Mol Cell Endocrinol. 2015;405:42-51.

26. Bousfield GR, Butnev VY, Walton WJ, Nguyen VT, Huneidi J, Singh V, Kolli VSK, Harvey DJ, Rance NE. All-or-none N-glycosylation in primate follicle-stimulating hormone $\beta$-subunits. Mol Cell Endocrinol. 2007;260-262:40-8

27. Levavi-Sivan B, Bogerd J, Mañanós EL, Gómez A, Lareyre JJ. Perspectives on fish gonadotropins and their receptors. Gen Comp Endocrinol. 2010;165:412-37.

28. Jacobs PP, Geysens S, Vervecken W, Contreras R, Callewaert N. Engineering complex-type N-glycosylation in Pichia pastoris using GlycoSwitch technology. Nat Protoc. 2009;4:58-70.

29. Aguiar FLN, Lunardi FO, Lima LF, Rocha RMP, Bruno JB, MagalhãesPadilha DM, Cibin FWS, Nunes-Pinheiro DCS, Gastal MO, Rodrigues APR, Apgar GA, Gastal EL, Figueiredo JR. FSH supplementation to culture medium is beneficial for activation and survival of preantral follicles enclosed in equine ovarian tissue. Theriogenology. 2016;85:1106-12.

30. Serafim MKB, Duarte ABG, Silva GM, Souza CEA, Magalhães-Padilha DM, Moura AAA, Silva LDM, Campello CC, Figueiredo JR. Impact of growth hormone $(\mathrm{GH})$ and follicle stimulating hormone (FSH) on in vitro canine preantral follicle development and estradiol production. Growth Horm IGF Res. 2015;25:85-9.

31. Rodrigues GQ, Manoel C, Silva G, Faustino LR, Bezerra J, Pinto LC, Afonso C, Lopes P, Campello CC, Figueiredo JR. Efeito de diferentes concentrações de hormônio folículo-estimulante recombinante sobre o desenvolvimento in vitro de folículos pré-antrais caprinos e ovinos isolados. Acta Vet Bras. 2010;4:144-52.

32. Meyers-Brown G, Bidstrup LA, Famula TR, Colgin M, Roser JF. Treatment with recombinant equine follicle stimulating hormone (reFSH) followed by recombinant equine luteinizing hormone (reLH) increases embryo recovery in superovulated mares. Anim Reprod Sci. 2011;128:52-9.

33. Tharasanit T, Colenbrander B, Bevers MM, Stout TAE. Effects of recombinant human follicle stimulating hormone on follicle development and ovulation in the mare. Theriogenology. 2006;65:1071-81.

34. Meyers-Brown GA, McCue PM, Troedsson MHT, Klein C, Zent W, Ferris RA, Lindholm ARG, Scofield DB, Claes AN, Morganti M, Colgin MA, Wetzel RL, Peters AR, Roser JF. Induction of ovulation in seasonally anestrous mares under ambient lights using recombinant equine FSH (reFSH). Theriogenology. 2013;80:456-62.

35. Fares FA, Suganuma N, Nishimori K, LaPolt PS, Hsueh AJ, Boime I. Design of a long-acting follitropin agonist by fusing the C-terminal sequence of the chorionic gonadotropin beta subunit to the follitropin beta subunit. Proc Natl Acad Sci USA. 1992;89:4304-8.

36. Fauser BCJM, Mannaerts MJL, Devroey P, Leader A, Boime I, Baird DT. Advances in recombinant DNA technology: Corifollitropin alfa, a hybrid molecule with sustained follicle-stimulating activity and reduced injection frequency. Hum Reprod Update. 2009;15:309-21.

37. Pouwer AW, Farquhar C, Kremer JAM. Long-acting FSH versus daily FSH for women undergoing assisted reproduction. Cochrane Database Syst Rev. 2015;7:CD009577.

38. Pouwer AW, Farquhar C, Kremer JA, Marjoribanks J. Long-acting follicle-stimulating hormone versus daily follicle-stimulating hormone for women undergoing assisted reproduction. Fertil Steril. 2016;105(6):1454-6.

39. Fachal MV, Furlan M, Clark R, Card CE, Chedrese PJ. Synthesis and characterization of biologically active recombinant elk and horse FSH. Anim Reprod Sci. 2010;117:331-40.

40. Rutigliano HM, Adams BM, Jablonka-Shariff A, Boime I, Adams TE. Effect of time and dose of recombinant follicle stimulating hormone agonist on the superovulatory response of sheep. Theriogenology. 2014:82:455-60.

41. Kutteyil SS, Pathak BR, Dighe RR, Mahale SD. Expression of bioactive callithrix jacchus follicle-stimulating hormone in Pichia pastoris. Appl Biochem Biotechnol. 2015;176:399-411.

42. Richard F, Robert P, Remy JJ, Martinat N, Bidart JM, Salesse R, Combarnous $Y$. High-level secretion of biologically active recombinant porcine follicle-stimulating hormone by the methylotrophic yeast Pichia pastoris. Biochem Biophys Res Commun. 1998;245:847-52.

43. Samaddar M, Catterall JF, Dighe RR. Expression of biologically active beta subunit of bovine follicle-stimulating hormone in the methylotrophic yeast Pichia pastoris. Protein Expr Purif. 1997;10:345-55.

44. Fidler AE, Lun S, Young W, McNatty KP. Expression and secretion of a biologically active glycoprotein hormone, ovine follicle stimulating hormone, by Pichia pastoris. J Mol Endocrinol. 1998;21:327-36.

45. Fidler AE, Lin JS, Lun S, Ng Chie W, Western A, Stent V, McNatty KP. Production of biologically active tethered ovine FSHbetaalpha by the methylotrophic yeast Pichia pastoris. J Mol Endocrinol. 2003;30:213-25.

46. Yu X, Lin S-W, Kobayashi M, Ge W. Expression of recombinant zebrafish follicle-stimulating hormone (FSH) in methylotropic yeast Pichia pastoris. Fish Physiol Biochem. 2010;36:273-81.

47. Chen J, Zhang Y, Tang Z, Mao J, Kuang Z, Qin C, Li W. Production of recombinant orange-spotted grouper (Epinephelus coioides) folliclestimulating hormone (FSH) in single-chain form and dimer form by Pichia pastor is and their biological activities. Gen Comp Endocrinol. 2012;178:237-49.

48. Aizen J, Kasuto H, Golan M, Zakay H, Levavi-Sivan B. Tilapia follicle-stimulating hormone (FSH): immunochemistry, stimulation by gonadotropin-releasing hormone, and effect of biologically active recombinant FSH on steroid secretion. Biol Reprod. 2007;76:692-700.

49. Kamei H, Ohira T, Yoshiura Y, Uchida N, Nagasawa H, Aida K. Expression of a biologically active recombinant follicle stimulating hormone of Japanese Eel Anguilla japonica using methylotropic yeast, Pichia pastoris. Gen Comp Endocrinol. 2003;134:244-54.

50. Ohta T, Miyake H, Miura C, Kamei H, Aida K, Miura T. Follicle-stimulating hormone induces spermatogenesis mediated by androgen production in Japanese eel, Anguilla japonica. Biol Reprod. 2007;77:970-7.

51. Qian W, Liu Y, Zhang C, Niu Z, Song H, Qiu B. Expression of bovine follicle-stimulating hormone subunits in a Hansenula polymorpha expression system increases the secretion and bioactivity in vivo. Protein Expr Purif. 2009;68:183-9.

52. Huo X, Liu Y, Wang X, Ouyang P, Niu Z, Shi Y, Qiu B. Co-expression of human protein disulfide isomerase (hPDI) enhances secretion of bovine follicle-stimulating hormone (bFSH) in Pichia pastoris. Protein Expr Purif. 2007;54:234-9.

53. Boze H, Laborde C, Chemardin P, Richard F, Venturin C, Combarnous $Y$, Moulin G. High-level secretory production of recombinant porcine follicle-stimulating hormone by Pichia pastoris. Process Biochem. 2001;36:907-13. 
54. Wilson M, Morris J, Gibbons J. Bioactive, bacterial-derived recombinant bovine follicle stimulating hormone. Reprod Fertil Dev. 2009;21:246-7.

55. Talmadge K, Vamvakopoulos NC, Fiddes JC. Evolution of the genes for the beta-subunits of human chorionic-gonadotropin and luteinizing hormone. Nature. 1984;307:37-40.

56. Matzuk MM, Hsueh AJW, LaPolt P, Tsafriri A, Keene JL, Boime I. The biological role of the carboxyl-terminal extension of human chorionic gonadotroin $\beta$-subunit. Endocrinology. 1990;126:376-83.

57. Nakav S, Dantes A, Pen S, Chadna-Mohanty P, Braw-Tal R, Amsterdam A Grotjan HE, Ben-Menahem D. Homologous and heterologous carboxyl terminal peptide (CTP) linker sequences enhance the secretion of bioactive single-chain bovine LH analogs. Exp Clin Endocrinol Diabetes. 2006:114:95-104.

58. Lemke EP, Adams BM, Jablonka-Shariff A, Boime I, Adams TE. Singlechain human gonadotropin analogs induce follicle development in sheep. J Endocrinol. 2008;196:593-600.

59. Braw-Tal R, Pen S, Grinberg M, Nakav S, Ben-Menahem D. The steroidogenic effect of single-chain bovine $\mathrm{LH}$ analogs in cultured bovine follicular cells. Mol Cell Endocrinol. 2006;252:136-41.

60. Altermatt $\mathrm{J}$, Marolf AJ, Wrigley RH, Carnevale EM. Effects of FSH and LH on ovarian and follicular blood flow, follicular growth and oocyte developmental competence in young and old mares. Anim Reprod Sci. 2012;133:191-7.

61. Bashir ST, Gastal MO, Tazawa SP, Tarso SGS, Hales DB, Cuervo-Arango J, Baerwald AR, Gastal EL. The mare as a model for luteinized unruptured follicle syndrome: intrafollicular endocrine milieu. Reproduction. 2016;151:271-83.

62. Viudes-de-Castro MP, Pomares A, Ribes MDS, Marco-Jiménez F, Vicente JS. Effect of luteinizing hormone on rabbit ovarian superstimulation and embryo developmental potential. Theriogenology. 2015:84:446-51.

63. Dinopoulou V, Drakakis P, Kefala S, Kiapekou E, Bletsa R, Anagnostou E, Kallianidis K, Loutradis D. Effect of recombinant-LH and hCG in the absence of FSH on in vitro maturation (IVM) fertilization and early embryonic development of mouse germinal vesicle (GV)-stage oocytes. Reprod Biol. 2016;16:138-46.

64. Hakola K, Boogaart PV, Mulders J, de Leeuw R, Schoonen W, Heyst JV, Swolfs A, Casteren JV, Huhtaniemi I, Kloosterboer H. Recombinant rat luteinizing hormone; production by Chinese hamster ovary cells, purification and functional characterization. Mol Cell Endocrinol. 1997;128:47-56.

65. Kaetzel DM, Browne JK, Wondisford F, Nett TM, Thomason AR, Nilson JH. Expression of biologically active bovine luteinizing hormone in Chinese hamster ovary cells. Proc Natl Acad Sci USA. 1985;82:7280-3.

66. Jablonka-Shariff A, Roser JF, Bousfield GR, Wolfe MW, Sibley LE, Colgin $\mathrm{M}$, Boime I. Expression and bioactivity of a single chain recombinant equine luteinizing hormone (reLH). Theriogenology. 2007;67:311-20.

67. Yoon MJ, Boime I, Colgin M, Niswender KD, King SS, Alvarenga M, Jablonka-Shariff A, Pearl CA, Roser JF. The efficacy of a single chain recombinant equine luteinizing hormone (reLH) in mares: induction of ovulation, hormone profiles, and inter-ovulatory intervals. Domest Anim Endocrinol. 2007:33:470-9.

68. Nakav S, Jablonka-Shariff A, Kaner S, Chadna-Mohanty P, Grotjan HE, Ben-Menahem D. The LH $\beta$ gene of several mammals embeds a carboxyl-terminal peptide-like sequence revealing a critical role for mucin oligosaccharides in the evolution of lutropin to chorionic gonadotropin in the animal phyla. J Biol Chem. 2005;280:16676-84.

69. Legardinier S, Duonor-Cérutti M, Devauchelle G, Combarnous Y, Cahoreau C. Biological activities of recombinant equine luteinizing hormone/chorionic gonadotropin (eLH/CG) expressed in Sf9 and Mimic insect cell lines. J Mol Endocrinol. 2005:34:47-60.

70. Legardinier S, Klett D, Poirier JC, Combarnous Y, Cahoreau C. Mammalian-like nonsialyl complex-type $\mathrm{N}$-glycosylation of equine gonadotropins in Mimic ${ }^{\text {TM }}$ insect cells. Glycobiology. 2005;15:776-90.

71. Legardinier S, Cahoreau C, Klett D, Combarnous Y. Involvement of equine chorionic gonadotropin (eCG) carbohydrate side chains in its bioactivity; lessons from recombinant hormone expressed in insect cells. Reprod Nutr Dev. 2005;45:255-9.

72. Gupta C, Dighe RR. Hyperexpression of biologically active human chorionic gonadotropin using the methylotropic yeast, Pichia pastoris. J Mol Endocrinol. 1999;22:273-83.
73. Blanchard V, Gadkari RA, Gerwig GJ, Leeflang BR, Dighe RR, Kamerling JP. Characterization of the $\mathrm{N}$-linked oligosaccharides from human chorionic gonadotropin expressed in the methylotrophic yeast Pichia pastoris. Glycoconj J. 2007;24:33-47.

74. Gadkari R, Deshpande R, Dighe RR. Hyperexpression and purification of biologically active human luteinizing hormone and human chorionic gonadotropin using the methylotropic yeast, Pichia pastoris. Protein Expr Purif. 2003;32:175-84.

75. Kasuto H, Levavi-Sivan B. Production of biologically active tethered tilapia LH $\beta$ a by the methylotrophic yeast Pichia pastoris. Gen Comp Endocrinol. 2005;140:222-32.

76. Huth JR, Norton SE, Lockridge O, Shikone T, Hsueh AJW, Ruddon RW. Bacterial expression and in vitro folding of the $\beta$-subunit of human chorionic gonadotropin (hCG $\beta$ ) and functional assembly of recombinant hCGß with hCGa. Endocrinology. 1994;135:911-8.

77. Mukhopadhyay A, Bhatia PK, Majumadar SS. Preliminary studies with recombinant chorionic gonadotropin P-Subunit produced in Escherichia coli for use as an antigen in a birth control vaccine. Am J Reprod Immunol. 1998;39:172-82.

78. Mukhopadhyay UK, Sahni G. Production of recombinant buffalo (Bubalus bubalis) and goat (Capra hircus) growth hormones from genetically modified E. coli strains. J Biotechnol. 2002;97:199-212.

79. George HJ, L'Italien JJ, Pilacinski WP, Glassman DL, Krzyzek RA. Highlevel expression in Escherichia coli of biologically active bovine growth hormone. DNA. 1985;4:273-81.

80. Wallis OC, Wallis M. Production of plasmids giving high expression of recombinant DNA-derived ovine growth hormone variants in Escherichia coli. FEBS Lett. 1989;250:371-6.

81. Vize PD, Wells JR. Isolation and characterization of the porcine growth hormone gene. Gene. 1987;55:339-44.

82. Austin EJ, Mihm M, Evans C, Knight PG, Ireland JL, Ireland JJ, Roche JF. Alterations in intrafollicular regulatory factors and apoptosis during selection of follicles in the first follicular wave of the bovine estrous cycle. Biol Reprod. 2001;64:839-48.

83. Lu C, Yang W, Chen M, Liu T, Yang J, Tan P, Li L, Hu X, Fan C, Hu Z, Liu Y. Inhibin A inhibits follicle-stimulating hormone (FSH) action by suppressing its receptor expression in cultured rat granulosa cells. Mol Cell Endocrinol. 2009:298:48-56.

84. Yan L, Li H, Shi Z. Immunization against inhibin improves in vivo and in vitro embryo production. Anim Reprod Sci. 2015;163:1-9.

85. Kaneko H, Watanabe G, Taya K, Sasamoto S. Changes in peripheral levels of bioactive and immunoreactive inhibin, estradiol-17 beta, progesterone, luteinizing hormone, and follicle-stimulating hormone associated with follicular development in cows induced to superovulate with equine chorionic gonad. Biol Reprod. 1992;47:76-82.

86. Squires EL, McCue PM. Superovulation in mares. Anim Reprod Sci. 2007;99:1-8.

87. Mei C, Li MY, Zhong SQ, Lei Y, Shi ZD. Enhancing embryo yield in superovulated holstein heifers by immunization against inhibin. Reprod Domest Anim. 2009:44:735-9.

88. Li DR, Qin GS, Wei YM, Lu FH, Huang QS, Juang HS, Shi DS, Shi ZD. Immunisation against inhibin enhances follicular development, oocyte maturation and superovulatory response in water buffaloes. Reprod Fertil Dev. 2011;23:788-97.

89. Liu YP, Mao XB, Wei YM, Yu JN, Li H, Chen RA, Shi ZD. Studies on enhancing embryo quantity and quality by immunization against inhibin in repeatedly superovulated Holstein heifers and the associated endocrine mechanisms. Anim Reprod Sci. 2013;142:10-8.

90. Bhardwaj A, Nayan V, Parvati, Mamta, Gupta AK. Inhibin: a role for fecundity augmentation in farm animals. Asian J Anim Vet Adv. 2012;7:771-89.

91. Bernard DJ. Disinhibiting an inhibitor: genetic engineering leads to improvements in recombinant inhibin a production. Endocrinology. 2016;157:2583-5.

92. Pangas SA, Woodruff TK. Production and purification of recombinant human inhibin and activin. J Endocrinol. 2002;172:199-210.

93. Moreau JD, Satterlee DG, Rejman JJ, Cadd GG, Kousoulas KG, Fioretti WC. Active immunization of Japanese quail hens with a recombinant chicken inhibin fusion protein enhances production performance. Poult Sci. 1998;77:894-901. 
94. Satterlee DG, Cadd GG, Fioretti WC. Active immunization of broiler breeder hens with a recombinant chicken inhibin fusion protein enhances egg lay. Poult Sci. 2002;81:519-28.

95. Satterlee DG, Castille SA, Fioretti WC. Active immunization of broiler breeder cockerels against chicken inhibin accelerates puberty and prevents age-induced testicular involution. Poult Sci. 2006;85:1087-94.

96. Medan MS, Akagi S, Kaneko H, Watanabe G, Tsonis CG, Taya K. Effects of re-immunization of heifers against inhibin on hormonal profiles and ovulation rate. Reproduction. 2004;128:475-82.

97. Bhardwaj A, Nayan V, Yadav P, De S, Datta TK, Goswami SL. Heterologous expression and characterization of indian sahiwal cattle (Bos indicus) alpha inhibin. Anim Biotechnol. 2012;23:71-88.

98. Holtz W, Wang X, El-Gayar M, Knight PG. The effect of exogenous gonadotropins on ovarian function in goats actively immunized against inhibin. Theriogenology. 2012;77:253-9.

99. Findlay JK, Doughton B, Robertson DM, Forage RG. Effects of immunization against recombinant bovine inhibin a subunit on circulating concentrations of gonadotrophins in ewes. J Endocrinol. 1989;120:59-65.

100. Forage RG, Brown RW, Oliver KJ, Atrache BT, Devine PL, Hudson GC, Goss NH, Bertram KC, Tolstoshev P, Robertson DM, Kretser DM, Doughton B, Burger HG, Findlay JK. Immunization against an inhibin subunit produced by recombinant DNA techniques results in increased ovulation rate in sheep. J Endocrinol. 1987;114:R1-4.

101. Voglmayr JK, Mizumachi M, Washington DW, Chen CLC, Bardin CW. Immunization of rams against human recombinant inhibin a-subunit delays, augments and extends season-related increase in blood gonadotropin levels. Biol Reprod. 1990;42:81-6.

102. Mizumachi M, Voglmayr JK, Washington DW, Chen CC, Bardin CW. Superovulation of Ewes immunized against the human recombinant inhibin a-Subunit associated with increased pre- and postovulatory follicle-stimulating hormone levels. Endocrinology. 1990;126:1058-63.

103. Anderson ST, Bindon BM, Hillard MA, O'Shea T. Increased ovulation rate in Merino ewes immunized against small synthetic peptide fragments of the inhibin alpha subunit. Reprod Fertil Dev. 1998;10:421-31.

104. D'Alessandro A, Martemucci G, laffaldano N. Active immunization with a synthetic fragment of pig inhibin a-subunit increases ovulation rate and embryo production in superovulated ewes but season affects its efficiency. J Reprod Fertil. 1999;115:185-91.

105. Mao D, Bai W, Hui F, Yang L, Cao S, Xu Y. Effect of inhibin gene immunization on antibody production and reproductive performance in Partridge Shank hens. Theriogenology. 2016;85(6):1037-44

106. Wrathall JH, McLeod BJ, Glencross RG, Knight PG. Effects of active immunization against a synthetic peptide sequence of the inhibin alpha-subunit on plasma gonadotrophin concentrations, ovulation rate and lambing rate in ewes. J Reprod Fertil. 1992;95:175-82.

107. O'Shea T, Bindon BM, Forage RG, Findlay JK, Tsonis CG. Active immunization of Merino ewe lambs with recombinant bovine alpha inhibin advances puberty and increases ovulation rate. Reprod Fertil Dev. 1993;5:173-80.

108. Buhler M, Limper J, Muller A, Schwarz G, Simon O, Sommer M, Spring W. Enzymes in animal nutrition. AWT (Arbeitsgemeinschaft für Wirkstoffe in der Tierernährung e. V.); 2013.

109. Choct M. Feed non-starch polysaccharides: chemical structures and nutritional significance. In: Feed Milling International; 1997(June Issue):13-26.

110. Motta FL, Andrade CCP, Santana MHA. A review of xylanase production by the fermentation of xylan : classification, characterization and applications. In: sustainable degradation of lignocellulosic biomasstechniques, applications and commercialization. Intech; 2015

111. Verma D, Satyanarayana T. Bioresource technology molecular approaches for ameliorating microbial xylanases. Bioresour Technol. 2012;117:360-7.

112. Tian B, Xu Y, Cai W, Huang Q, Gao Y, Huang J. Molecular Cloning and Overexpression of an Endo- $\beta$-1, 4-xylanase Gene from Aspergillus niger in industrial Saccharomyces cerevisiae YS2 strain. Appl Environ Microbiol. 2013;170:320-8.

113. Lei XG, Weaver JD, Mullaney E, Ullah AH, Azain MJ. Phytase, a new life for an "old" enzyme. Annu Rev Anim Biosci. 2013;1:283-309.

114. Juturu V, Wu JC. Microbial exo-xylanases: a mini review. Appl Biochem Biotechnol. 2014;174(1):81-92
115. Adeola O, Cowieson AJ. BOARD-INVITED REVIEW: opportunities and challenges in using exogenous enzymes to improve nonruminant animal production. J Anim Sci. 2014;89:3189-218.

116. Ahmed S, Riaz S, Jamil A. Molecular cloning of fungal xylanases: an overview. Appl Microbiol Biotechnol. 2009;84:19-35.

117. Juturu V, Wu JC. Microbial xylanases: engineering, production and industrial applications. Biotechnol Adv. 2012:30:1219-27.

118. Knob A, Terrasan CRF, Carmona EC. $\beta$-Xylosidases from filamentous fungi: an overview. World J Microbiol Biotechnol. 2010;26:389-407.

119. Gencoglu H, Shaver RD, Steinberg W, Ensink J, Ferraretto LF, Bertics SJ, Lopes JC, Akins MS. Effect of feeding a reduced-starch diet with or without amylase addition on lactation performance in dairy cows. J Dairy Sci. 2010;93:723-32.

120. Ferraretto LF, Shaver RD, Espineira M, Gencoglu H, Bertics SJ. Influence of a reduced-starch diet with or without exogenous amylase on lactation performance by dairy cows. J Dairy Sci. 2011;94:1490-9.

121. Weiss WP, Steinberg W, Engstrom MA. Milk production and nutrient digestibility by dairy cows when fed exogenous amylase with coarsely ground dry corn. J Dairy Sci. 2011;94:2492-9.

122. McCarthy MM, Engstrom M, Azem E, Gressley TF. The effect of an exogenous amylase on performance and total-tract digestibility in lactating dairy cows fed a high-byproduct diet. J Dairy Sci. 2013;96:3075-84.

123. Nozière P, Steinberg W, Silberberg M, Morgavi DP. Amylase addition increases starch ruminal digestion in first-lactation cows fed high and low starch diets. J Dairy Sci. 2014;97:2319-28.

124. Ravindran V, Son J. Feed enzyme technology: present status and future developments. Recent Pat Food Nutr Agric. 2011;3:102-9.

125. Stewart EJ, Aslund F, Beckwith J. Disulfide bond formation in the Escherichia coli cytoplasm: an in vivo role reversal for the thioredoxins. EMBO J. 1998;17:5543-50.

126. Gündüz Ergün B, Çalık P. Lignocellulose degrading extremozymes produced by Pichia pastoris: current status and future prospects. Bioprocess Biosyst Eng. 2016;39:1-36.

127. He J, Yin J, Wang L, Yu B, Chen D. Functional characterisation of a recombinant xylanase from Pichia pastoris and effect of the enzyme on nutrient digestibility in weaned pigs British Journal of Nutrition. $\mathrm{Br}$ J Nutr. 2010;103:1507-13.

128. Li Y, Zhang B, Chen X, Chen Y. Improvement of Aspergillus sulphureus Endo- $\beta-1,4-x y l a n a s e$ expression in Pichia pastoris by codon optimization and analysis of the enzymic characterization. Appl Biochem Biotechnol. 2010;160:1321-31

129. Liu M, Weng X, Sun J. Expression of recombinant Aspergillus niger xylanase A in Pichia pastoris and its action on xylan. Protein Expr Purif. 2006:48:292-9.

130. Fang W, Gao H, Cao Y, Shan A. Cloning and expression of a xylanase xynB from Aspergillus niger IA-001 in Pichia pastoris. J Basic Microbiol. 2014;54:S190-9.

131. Fu X-Y, Zhao W, Xiong A-S, Tian Y-S, Peng R-H. High expression of recombinant Streptomyces sp. S38 xylanase in Pichia pastoris by codon optimization and analysis of its biochemical properties. Mol Biol Rep. 2011:38:4991-7.

132. Luttig M, Pretorius IS, van ZyI WH. Cloning of two $\beta$-xylanase-encoding genes from Aspergillus niger and their expression in Saccharomyces cerevisiae. Biotechnol Lett. 1997;19:411-5.

133. Görgens JF, Planas J, Van Zyl WH, Knoetze JH. Comparison of three expression systems for heterologous xylanase production by S. cerevisiae in defined medium. Yeast. 2004;21:1205-17.

134. Yi X, Shi Y, Xu H, Li W, Xie J, Yu R, Zhu J, Cao Y, Qiao D. Hyperexpression of two Aspergillus niger xylanase genes in Escherichia coli and characterization of the gene products. Braz J Microbiol. 2010;41:778-86.

135. Jun $H$, Bing $Y$, Keying Z, Xuemei D, Daiwen C. Expression of a Trichoderma reesei $b$-xylanase gene in Escherichia coli and activity of the enzyme on fiber-bound substrates. Protein Expr Purif. 2009;67:1-6.

136. Shi H, Zhang Y, Zhong H, Huang Y, Li X, Wang F. Cloning, over-expression and characterization of a thermo- tolerant xylanase from Thermotoga thermarum. Biotechnol Lett. 2014;36:587-93.

137. Graciano L, Corrêa J, Vieira F, Bosetto A, Loth E, Kadowaki M, Gandra R, de Simão CG. Cloning and expression of the xynA1 gene encoding a xylanase of the GH10 group in Caulobacter crescentus. Appl Biochem Biotechnol. 2015;175:3915-29. 
138. Huang X, Li Z, Du C, Wang J, Li S. Improved Expression and characterization of a multidomain xylanase from thermoanaerobacterium aotearoense SCUT27 in Bacillus subtilis. J Agric Food Chem. 2015;63:6430-9.

139. Pontonio E, Mahony J, Di Cagno R, Motherway MOC, Lugli GA, Callaghan AO, De Angelis M, Ventura M, Gobbetti M, Van Sinderen D. Cloning, expression and characterization of a $\beta$-D-xylosidase from Lactobacillus rossiae DSM 15814T. Microb Cell Fact. 2016;15:1-12.

140. Hsueh H, Yu B, Liu C, Liu J. Increase of the adhesion ability and display of a rumen fungal xylanase on the cell surface of Lactobacillus casei by using a listerial cell-wall-anchoring protein. J Sci Food Agric. 2014;94(May):576-84.

141. Jain KK, Dey TB, Kumar S, Kuhad RC. Production of thermostable hydrolases (cellulases and xylanase) from Thermoascus aurantiacus RCKK: a potential fungus. Bioprocess Biosyst Eng. 2015;38:787-96.

142. Haefner MS, Knietsch A, Scholten E, Braun J, Lohscheidt M, Zelder O. Biotechnological production and applications of phytases. Appl Microbiol Biotechnol. 2005:68:588-97.

143. Kebreab E, Hansen AV, Strathe AB. Animal production for efficient phosphate utilization: from optimized feed to high efficiency livestock. Curr Opin Biotechnol. 2012;23:872-7.

144. Coumar MV, Singh S, Satyanarayana T. Availability and utilization of phosphorus from rock phosphate enriched biogas slurry under mustard. J Nucl Agric Biol. 2004;33:154-63.

145. Kornegay ET. Effectiveness of Natuphos phytase in improving the bioavailability of phosphorus and other nutrients in corn-soybean meal diet for young pigs. In: Coelho MB, Kornegay ET, editors. Phytase in animal nutrition and waste management. Mount Olive: BASF Corporation; 1996. p. 249-58.

146. Rao DECS, Rao KV, Reddy TP, Reddy VD. Molecular characterization, physicochemical properties, known and potential applications of phytases: an overview. Crit Rev Biotechnol. 2009;29:182-98.

147. Jain J, Singh B. Characteristics and biotechnological applications of bacterial phytases. Process Biochem. 2016;51:159-69.

148. Kaur P, Kunze G, Satyanarayana T. Yeast phytases: present scenario and future perspectives. Crit Rev Biotechnol. 2007;27:93-109.

149. Mukhametzyanova AD, Akhmetova Al, Sharipova MR. Microorganisms as phytase producers. Microbiology. 2012;81:267-75.

150. Lassen SF, Breinholt J, Østergaard PR, Brugger R, Bischoff A, Wyss $M$, Fuglsang CC. Expression, gene cloning, and characterization of five novel phytases from four basidiomycete fungi: Peniophora lycii, Agrocybe pediades, a Ceriporia sp., and Trametes pubescens. Appl Environ Microbiol. 2001;67:4701-7

151. Wyss M, Pasamontes L, Rémy R, Kohler J, Kusznir E, Gadient M, Müller F, van Loon APGM. Comparison of the thermostability properties of three acid phosphatases from molds: Aspergillus fumigatus Phytase, A. niger Phytase, and A. niger PH 2.5 acid phosphatase. Appl Environ Microbiol. 1998:64:4446-51.

152. Pasamontes $L$, Haiker M, Wyss M, Tessier M, van Loon APGM Gene cloning, purification, and characterization of a heat-stable phytase from the fungus Aspergillus fumigatus. Appl Environ Microbiol. 1997;63:1696-700.

153. Berka RM, Rey MW, Brown KM, Byun T, Klotz AV. Molecular characterization and expression of a phytase gene from the thermophilic fungus Thermomyces lanuginosus. Appl Environ Microbiol. 1998;64(11):4423-7.

154. Chadha BS, Harmeet G, Mandeep M, Saini HS, Singh N. Phytase production by the thermophilic fungus Rhizomucor pusillus. World J Microbiol Biotechnol. 2004;20(1):105-9.

155. Kaur P, Satyanarayana T. Production of cell-bound phytase by Pichia anomala in an economical cane molasses medium: optimization using statistical tools. Process Biochem. 2005:40:3095-102.

156. Hedegaard CJ, Heegaard PMH. Passive immunisation, an old idea revisited: basic principles and application to modern animal production systems. Vet Immunol Immunopathol. 2016;174:50-63.

157. Holliger P, Hudson PJ. Engineered antibody fragments and the rise of single domains. Nat Biotechnol. 2005;23:1126-36.

158. Enjuanes L, Van der Zeijst BA. Molecular basis of transmissible gastroenteritis virus epidemiology. In: Siddell SG, editor. The coronaviridae. New York: Plenum Press; 1995. p. 337-76.

159. Winter G, Milstein C. Man-made antibodies. Nature. 1991;349:293-9.

160. Bestagno M, Sola I, Dallegno E, Sabella P, Poggianella M, Plana-Duran J, Enjuanes L, Burrone OR. Recombinant dimeric small immunoproteins neutralize transmissible gastroenteritis virus infectivity efficiently in vitro and confer passive immunity in vivo. J Gen Virol. 2007;88:187-95.

161. Koti M, Farrugia W, Nagy E, Ramsland PA, Kaushik AK. Construction of single-chain Fv with two possible CDR3H conformations but similar inter-molecular forces that neutralize bovine herpesvirus 1. Mol Immunol. 2010;47:953-60.

162. Pasman Y, Nagy E, Kaushik AK. Enhanced bovine herpesvirus type 1 neutralization by multimerized single-chain variable antibody fragments regardless of differential glycosylation. Clin Vaccin Immunol. 2012;19:1150-7.

163. Harmsen MM, Fijten HPD, Engel B, Dekker A, Eblé PL. Passive immunization with llama single-domain antibody fragments reduces foot-andmouth disease transmission between pigs. Vaccine. 2009;27:1904-11.

164. de Marco A. Biotechnological applications of recombinant singledomain antibody fragments. Microb Cell Fact. 2011;10:44.

165. Wang M, Zhang Y, Li B, Zhu J. Construction of scFv that bind both fibronectin-binding protein A and clumping factor A of Stapylococcus aureus. Res Vet Sci. 2015;100:109-14.

166. Sordillo LM, Campos M, Babiuk LA. Antibacterial activity of bovine mammary gland lymphocytes following treatment with interleukin-2. J Dairy Sci. 1991;74:3370-5.

167. Zecconi A, Piccinini R, Fiorina S, Cabrini L, Daprà V, Amadori M. Evaluation of interleukin-2 treatment for prevention of intramammary infections in cows after calving. Comp Immunol Microbiol Infect Dis. 2009:32:439-51.

168. Takahashi H, Komatsu T, Hodate K, Horino R, Yokomizo Y. Effect of intramammary injection of RblL-8 on milk levels of somatic cell count, chemiluminescence activity and shedding patterns of total bacteria and S. aureus in holstein cows with naturally infected-subclinical mastitis. J Vet Med. 2005;52:33-7.

169. Daley MJ, Coyle PA, Williams TJ, Furda G, Dougherty R, Hayes PW. Staphylococcus aureus Mastitis: pathogenesis and treatment with bovine interleukin-1ß and interleukin-2. J Dairy Sci. 1991:74:4413-24.

170. Wedlock DN, McCarthy AR, Doolin EE, Lacy-Hulbert SJ, Woolford MW, Buddle BM. Effect of recombinant cytokines on leucocytes and physiological changes in bovine mammary glands during early involution. J Dairy Res. 2004;71:154-61.

171. Kimura K, Goff JP, Canning P, Wang C, Roth JA. Effect of recombinant bovine granulocyte colony-stimulating factor covalently bound to polyethylene glycol injection on neutrophil number and function in periparturient dairy cows. J Dairy Sci. 2014;97:4842-51.

172. Saugandhika S, Sharma V, Malik H, Saini S, Bag S, Kumar S, Singh NK, Mohanty AK, Malakar D. Expression and purification of buffalo interferon-tau and efficacy of recombinant buffalo interferon-tau for in vitro embryo development. Cytokine. 2015;75:186-96.

173. Matsunaga S, Osawa T, Geshi M, Takahashi H, Inumaru S, Yokomizo Y, Miyake YI. Effect of a single intrauterine administration of recombinant bovine interferon- $\tau$ on day 7 of the estrous cycle on the luteal phase length and blood profile in dairy cows. Res Vet Sci. 2012;93:381-5.

174. Shirasuna K, Matsumoto $\mathrm{H}$, Matsuyama S, Kimura K, Bollwein $\mathrm{H}_{\text {, }}$ Miyamoto A. Possible role of interferon tau on the bovine corpus luteum and neutrophils during the early pregnancy. Reproduction. 2015;150:217-25.

175. Dang-Nguyen TQ, Haraguchi S, Kikuchi K, Somfai T, Bodó S, Nagai T. Leukemia inhibitory factor promotes porcine oocyte maturation and is accompanied by activation of signal transducer and activator of transcription 3. Mol Reprod Dev. 2014;81:230-9.

176. Morris KR, Bean AGD, Bruce MP, Broadway MM, O'Neil TE, Andrew ME, Emmins JJ, Strom DG. Administration of porcine interleukin-3 induces increased levels of blood eosinophils. J Interf cytokine Res. 2008;28:435-44.

177. Lillehoj HS, Choi KD. Recombinant chicken interferon-gamma-mediated inhibition of Eimeria tenella development in vitro and reduction of oocyst production and body weight loss following Eimeria acervulina challenge infection. Avian Dis. 1998;42:307-14.

178. Lowenthal JW, York JJ, O'Neil TE, Rhodes S, Prowse SJ, Strom DG, Digby MR. In vivo effects of chicken interferon-gamma during infection with Eimeria. J Interf cytokine Res. 1997;17:551-8.

179. Domènech A, Raynes JG, Rodríguez EM, Arís A, Bach A, Serrano A. recombinant expression of goat milk serum amyloid $A$ : preliminary 
studies of the protein and derived peptides on Macrophage Phagocytosis. Protein Pept Lett. 2012;19:299-307.

180. Domènech A, Parés S, Bach A, Arís A. Mammary serum amyloid A3 activates involution of the mammary gland in dairy cows. J Dairy Sci. 2014;97:7595-605.

181. Kufner K, Lipps G. Construction of a chimeric thermoacidophilic betaendoglucanase. BMC Biochem. 2013;14:1-9.

182. García-Fruitós E. Lactic acid bacteria: a promising alternative for recombinant protein production. Microb Cell Fact. 2012;11:157.

183. García-Fruitós E, editor. Insoluble proteins, vol. 1258. New York: Humana Press; 2015.

184. Cano-Garrido O, Seras-Franzoso J, Garcia-Fruitós E. Lactic acid bacteria: reviewing the potential of a promising delivery live vector for biomedical purposes. Microb Cell Fact. 2015;14:137.

185. Shi B, Ke X, Yu H, Xie J, Jia Y, Guo R. Novel properties for endoglucanase acquired by cell-surface display technique. J Microbiol Biotechnol. 2015;25:1856-62.

186. Villaverde A, Corchero JL, Seras-Franzoso J, Garcia-Fruitós E. Functional protein aggregates: just the tip of the iceberg. Nanomedicine. 2015;10:2881-91.

187. Villaverde A, García-Fruitós E, Rinas U, Seras-Franzoso J, Kosoy A, Corchero JL, Vazquez E. Packaging protein drugs as bacterial inclusion bodies for therapeutic applications. Microb Cell Fact. 2012;11:76.

188. Doglia SM, Lotti M, editors. Protein aggregation in bacteria: functional and structural properties of inclusion bodies in bacterial cells. Hoboken: Wiley; 2014.

189. García-Fruitós E, Vázquez E, Díez-Gil C, Corchero JL, Seras-Franzoso J Ratera I, Veciana J, Villaverde A. Bacterial inclusion bodies: making gold from waste. Trends Biotechnol. 2012:30:65-70.

190. Singh SM, Panda AK. Solubilization and refolding of bacterial inclusion body proteins. 2005:99:303-10.

191. Panda AK. Bioprocessing of therapeutic proteins from the inclusion bodies of Escherichia coli. Adv Biochem Eng Biotechnol. 2003;85:43-93.
192. Torrealba D, Parra D, Seras-Franzoso J, Vallejos-Vidal E, Yero D, Gibert I, Villaverde A, Garcia-Fruitós E, Roher N. Nanostructured recombinant cytokines: a highly stable alternative to short-lived prophylactics. Biomaterials. 2016;107:102-14.

193. Rueda F, Gasser B, Chardi AS, Roldán M, Villegas S. Functional inclusion bodies produced in the yeast Pichia pastoris functional inclusion bodies produced in the yeast Pichia pastoris. Microb Cell Fact. 2016;15:166.

194. Cano-Garrido O, Sánchez-Chardi A, Parés S, Giró I, Tatkiewicz WI, FerrerMiralles N, Ratera I, Natalello A, Cubarsi R, Veciana J, Bach À, Villaverde A, Arís A, Garcia-Fruitós E. Functional protein-based nanomaterial produced in GRAS microorganism: a new platform for biotechnology. Acta Biomater. 2016;43:230-9.

195. Pachioni-Vasconcelos JA, Lopes AM, Apolinário AC, Valenzuela-Oses JK, Costa JSR, Nascimento L, Pessoa A Jr, Barbosad LRS, Rangel-Yagui C. Nanostructures for protein drug delivery. Biomater Sci. 2016:4:205-18.

196. Palivan CG, Goers R, Najer A, Zhang X, Cara A, Meier W. Bioinspired polymer vesicles and membranes for biological and medical applications. Chem Soc Rev. 2016:45:377-411.

197. Pagels RF, Prud'homme RK. Polymeric nanoparticles and microparticles for the delivery of peptides, biologics, and soluble therapeutics. J Control Release. 2015;219:519-35.

198. Ibraheem D, Elaissari A, Fessi H. Gene therapy and DNA delivery systems. Int J Pharm. 2014;459:70-83.

199. Diwan M, Dawar H, Talwar GP. Induction of early and bioeffective antibody response in rodents with the luteinizing hormone-releasing hormone vaccine given as a single dose in biodegradable microspheres along with alum. Prostate. 1998;35:279-84.

200. Zeng S, Du L, Huang M, Feng J. Biological synthesis of Au nanoparticles using liquefied mash of cassava starch and their functionalization for enhanced hydrolysis of xylan by recombinant xylanase. Bioprocess Biosyst Eng. 2016;19:785-92.

\section{Submit your next manuscript to BioMed Central and we will help you at every step:}

- We accept pre-submission inquiries

- Our selector tool helps you to find the most relevant journal

- We provide round the clock customer support

- Convenient online submission

- Thorough peer review

- Inclusion in PubMed and all major indexing services

- Maximum visibility for your research

Submit your manuscript at www.biomedcentral.com/submit
O Biomed Central 